\title{
Los DEPÓSITOS DE LA RÍA DE HuELVA: EN BUSCA DEL BARCO PERDIDO
}

\author{
Jesús M. FERnÁNdez RodrígueZ \\ Departamento de Ciencias Sociales, IES San Andrés, Santa Cruz de Tenerife
}

Recibido: 21/01/2014

Revisado: 13/03/2014
Aceptado: $18 / 03 / 2014$

Publicado: 20/05/2014

\section{RESUMEN}

En este artículo se revisan los diversos hallazgos fluviales recuperados durante el siglo pasado en la ría de Huelva. Se analiza el contexto geográfico, las circunstancias de tales hallazgos, los tipos de artefactos, sus cronologías y simbolismo. Se estudian también las diferentes hipótesis que se han vertido acerca de los motivos de su deposición, para concluir que el estuario onubense representa un lugar de memoria en el que fueron amortizados un conjunto de depósitos votivos de larga duración, como se testifica desde el Bronce Final en numerosos territorios europeos.

\section{Palabras Clave}

Suroeste ibérico; Bronce Final; Depósito votivo; Armas; Arqueología de la Religión.

\section{ABSTRAC}

This article reviews the different river finds recovered during the last century in the ria of Huelva. Discusses the geographical context, the circumstances of the findings, the types of artefacts, their chronologies and symbolism. Also explores the different hypotheses that have been poured on the grounds of his deposition, to conclude that the Huelva estuary represents a place of memory in which were depreciated a set of votive of longterm hoards, as testifies from the Late Bronze in many European territories.

\section{KEYWORDS}

Southwestern Iberia; Late Bronze; Votive hoards; Weapons; Archaeology of Religion.

jesuferrod@hotmail.com 
Uno de los hallazgos más relevantes del Bronce Final andaluz acontecido en el primer cuarto del siglo XX ha sido el del denominado depósito de bronces de la ría de Huelva, formado por una serie variada de objetos metálicos que desde el principio fue conocido en la literatura arqueológica como el “depósito de La Ría de Huelva”. A partir de los informes y algunos breves artículos publicados desde su extracción en el Odiel, los materiales arqueológicos recuperados fueron bien estudiados por M. Almagro Basch (1940 y 1958) en un trabajo que ha servido de referencia para los otros estudios que se han hecho con posterioridad. El inventario y análisis de este depósito ha ido completándose paulatinamente hasta llegar a la monografía colectiva sobre el yacimiento, editada por M. Ruiz-Gálvez (1995a), y el estudio de algunos de sus materiales, especialmente las espadas (Meijide, 1988; Brandherm, 2007). Caben pocas reservas sobre el hecho de que estamos ante uno de los hallazgos arqueológicos que ha suscitado mayor controversia y volumen de bibliografía de la protohistoria peninsular. Es más, podemos afirmar sin temor a equivocarnos que la discusión sobre su funcionalidad y cronología sigue abierta y, probablemente, seguirá estándolo durante mucho tiempo. Por otra parte, conviene recordar también que el depósito dragado en el año 1923 ha eclipsado a otros conjuntos de piezas, halladas igualmente en aguas de la ría, a poca distancia del depósito, que contribuyen a reforzar el carácter sagrado y votivo del antiguo estuario onubense y de los materiales que a lo largo de los siglos fueron depositándose ritualmente en sus aguas.

En este artículo abordaremos la historia de los múltiples hallazgos arqueológicos dragados o aparecidos en la ría, con mención a tales materiales y a los estudios que se han ocupado de ellos, dedicando un apartado en exclusividad al conjunto de bronces exhumados en el año 1923, por el volumen y significado de los materiales recuperados. A este respecto, es indispensable establecer un inventario justo de lo que se sabe y de lo que han prestado los arqueólogos. Nuestro propósito es, además, mostrar que el carácter sagrado del lugar no se reduce simplemente al importante depósito de armas, arreos, elementos de vestido y adorno hallados en 1923, sino que contamos con otros materiales de diferentes procedencias del estuario que convergen en la naturaleza sagrada de la ría: armas y otros elementos exhumados en 1923, el casco corintio hallado en el año 1930, los "smiting gods" o figuras de
Melkart, procedentes de la barra de Saltés, y otras piezas dragadas en distintas zonas del puerto, etc. Parece que las diversas culturas (tartesios, fenicios y griegos) que convivieron en la Onuba prerromana aceptaron plenamente el carácter votivo de dichas aguas fluviomarinas.

\section{El CONTEXTO Y LOS MATERIALES: UN "PAISAJE DE} AGUA"

En el presente apartado se esbozan algunas características paleotopográficas del estuario para comprender el carácter simbólico de la ría y de los depósitos materiales arrojados a sus aguas. En tal sentido, la importancia del lugar debe entenderse en un contexto geográfico e histórico más amplio, pues el suroeste peninsular se convierte durante el Bronce Final en un punto intermedio entre el Atlántico y el Mediterráneo, Europa y África y entre Oriente y Occidente. Una buena parte de su litoral ofrece buenos puertos naturales en los estuarios, que permiten las comunicaciones con el interior y el acceso a sus riquezas. La posición estratégica de este territorio, los recursos disponibles en la zona para el intercambio, una cierta infraestructura de zonas de atraque, las verosímiles "facilidades" para hacerlo por parte de las élites locales, así como las posibilidades de penetración desde la costa hacia el interior peninsular, otorgaron al suroeste un papel privilegiado, como se atestigua a través de los cada vez más abundantes restos arqueológicos foráneos que lo confirman (Ruiz-Gálvez, 2013). Conviene recordar, así mismo, el significado acuático contenido en el topónimo indoeuropeo Onuba y otros, para reforzar la vocación fluvial y marina del territorio.

Aunque resulte ocioso insistir en el notable valor geoestratégico que tuvo la ría y su función como vía principal de penetración hacia unas tierras del interior, ricas en recursos ganaderos, salinas, pescado, minerales y otras materias perecederas, estudiar la importancia política y simbólica del hábitat protohistórico de Huelva y del depósito de bronces exige recordar que los ríos Tinto y Odiel formaban un amplio estuario o golfo marino emplazado en la parte media y más entrante del Golfo de Cádiz. Se encontraba equidistante de los importantes ríos Guadiana y Guadalquivir, y próximo a Cádiz, a tan sólo 50 millas marinas, menos de unos $100 \mathrm{kms}$ de distancia. En la confluencia de los citados ríos onubenses aparece la península de Huelva, dominada por un conjunto de cabezos de origen terciario, desde los que se ejerce el control de la bahía y de las tierras 
que por el norte riega el río de la Anicoba, de agua dulce. Precisamente, esta confluencia conformó una desembocadura hasta época histórica, integrada por algunas islas arenosas en el interior del estuario y en la desembocadura frente al mar abierto: Punta Umbría y los islotes de la barra de Saltés. Durante la Edad del Bronce esta desembocadura era más amplia y la línea de costa llegaba hasta las actuales poblaciones de El Aljaraque, Gibraleón, San Juan de Aznalfarache y La Rábida. Todas estas características dotaron a Onuba de unas condiciones excepcionales: buen puerto, dominio de las vías marítimas y fluviales, presencia de tierras fértiles por el norte de los cabezos hacia el istmo del río Anicoba, favorables condiciones para la obtención de recursos marinos o para la extracción de sal marina, etc. Y, no menos importante, los ríos Tinto y Odiel constituyeron auténticas vías naturales de penetración hacia los recursos mineros del interior y hacia, y desde las dehesas ganaderas del suroeste, documentadas desde el IV milenio (Ruiz-Gálvez, 1995a, 17).

Junto con el importante lote de bronces dragado en el río Odiel en 1923, en años sucesivos la arqueología protohistórica es testigo de la recuperación de diferentes materiales en la ría de Huelva, encontrados en circunstancias no bien precisadas y en diferentes lugares del estuario onubense. Por su propia naturaleza y número, parece difícil catalogarlos como objetos procedentes del cargamento de barcos hundidos o el resultado de pérdidas casuales, salvo un anzuelo de bronce. Así, en el año 1930, como resultado también de nuevos dragados en la ría, se produce el hallazgo de un casco griego más al sur del anterior depósito, en el actual fondeadero del puerto (Albelda y Obermaier, 1988). Se trata de un casco corintio de bronce (depositado en la Real Academia de la Historia), decorado con palmetas y flores de loto en el extremo exterior de las aberturas para los ojos (figura 1). Se le otorga una cronología del siglo VII-VI a.C. (Olmos, 1988).

En el año 1944, J. Terrero publica cuatro nuevos hallazgos metálicos procedentes de distintos dragados, especificando que no fueron encontrados ni en el mismo lugar ni en las mismas fechas que las anteriores. Estos objetos eran un anzuelo, un cazo o simpulo y dos fíbulas anulares hispánicas, estudiadas por E. Cuadrado (1969). No se apunta el lugar exacto del hallazgo.

Con serias dudas sobre su ubicación, E. Llobregat (1963) divulga en el VIII Congreso Nacional de Arqueología el estudio de una espada onubense so-

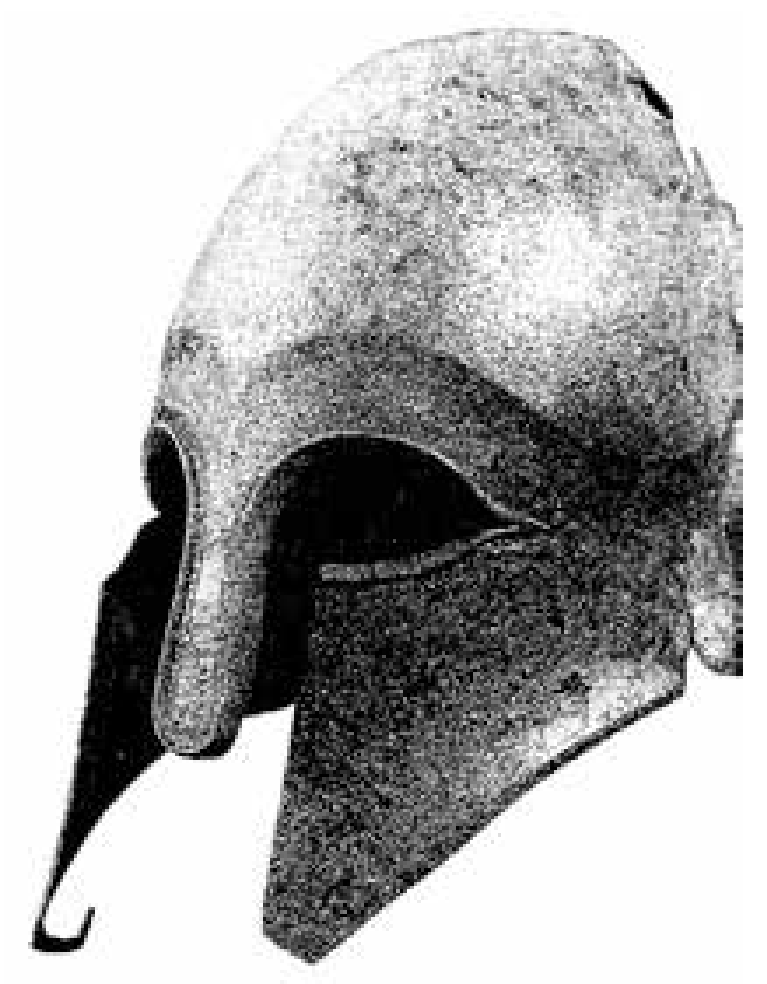

Figura 1. Casco griego recuperado en la ría de Huelva (según Blázquez y García Gelabert, 1997, 106).

bre la que se vierte una información contradictoria, al decir primero que fue dragada junto al conjunto de objetos metálicos del año 1923, y posteriormente comentar que este arma fue encontrada casualmente en la playa tiempo después del famoso hallazgo.

De un modo también impreciso desde el punto de vista de su localización, P. Rouillard (1977) analiza un fragmento de aríbalos corintio hallado en la ría de Huelva, y que podría datarse en el Corintio Medio, entre el 590-560a.C. El resto cerámico conservado presenta decoración de un animal con el perfil dirigido a la izquierda; según el arqueólogo, se trataría de un macho cabrío (figura 2).

Con una localización un poco más exacta, fueron exhumadas en la Barra de Huelva dos conocidas figuras de bronce que responden a la iconografía de los "smiting gods", y que se identifican con la imagen del dios fenicio Melkart (Gamer-Wallert, 1982). A los bronces hallados en la Barra de Huelva, habría que añadir todavía otros dos más. Ambos han sido dados a conocer recientemente por E. Ferrer. Del primero parece clara su procedencia subacuática, aunque su localización exacta no tanto. Las referencias disponibles permiten sugerir una recuperación 


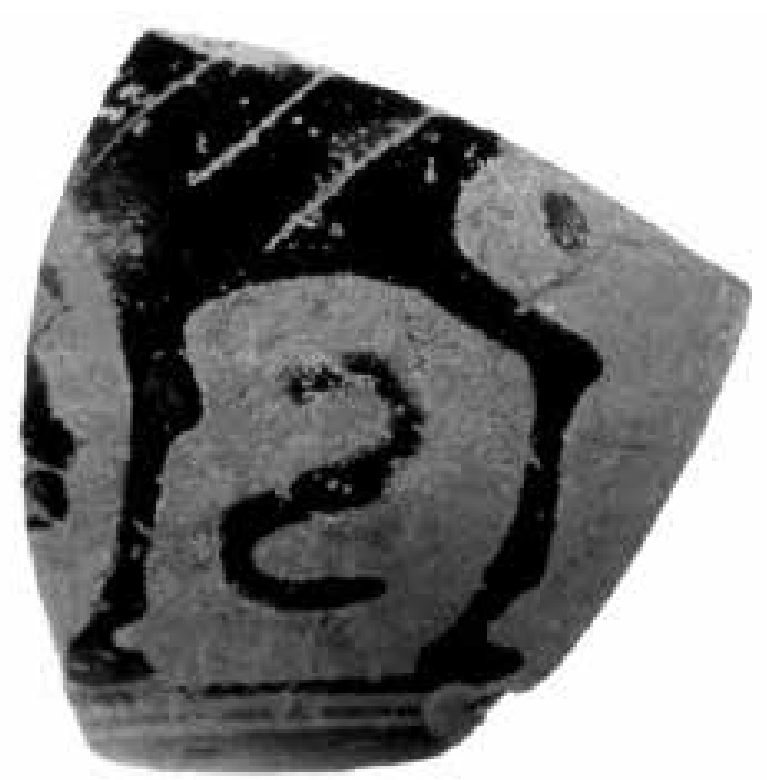

Figura 2. Fragmento de cerámica corintia hallada de forma casual en la ría de Huelva (Fotografía: Museo Arqueológico de Huelva).
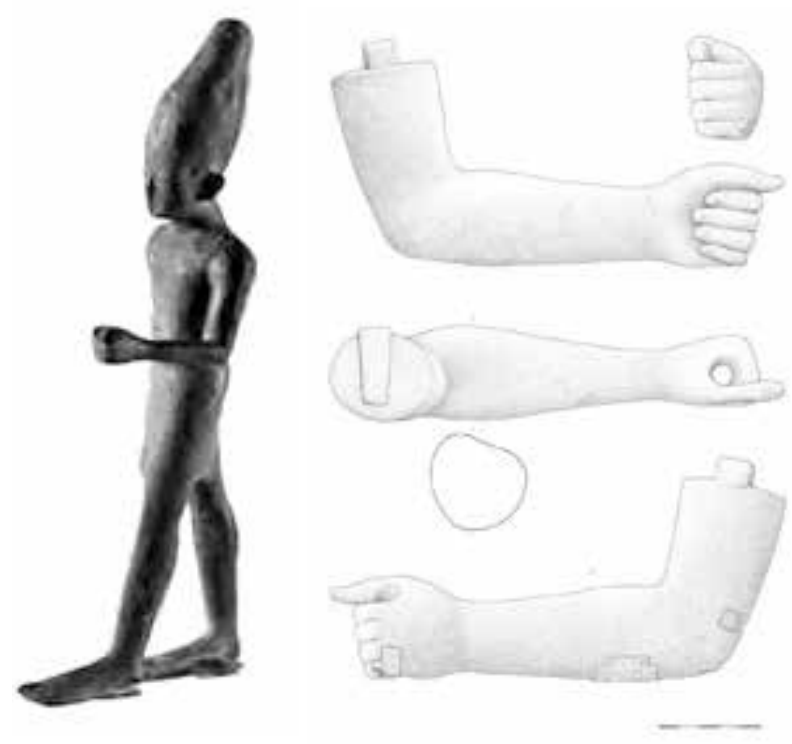

Figura 3. A la izquierda, "smiting god" procedente de la ría de Huelva (Fotografía: Museo Arqueológico de Huelva); a la derecha, restos de un brazo de bronce de la colección Albelda, perteneciente a otro "dios que golpea"; pudo haber sido recuperado también del fondo de la ría onubense (según Ferrer, 2012). de los fondos de la ría onubense. Se trata de un brazo de bronce que formó parte de la representación de un "smiting god" de gran peso (cerca de los $50 \mathrm{~kg}$ ) y tamaño (en torno a $1 \mathrm{~m}$ ) (figura 3 ). El segundo bronce se encuentra en paradero desconocido, si bien sabemos que fue hallado durante la construcción de la Refinería de Petróleos de Torre Arenillas, en el polo industrial de Huelva. Dispondríamos, pues, de al menos cuatro ejemplares en total (Ferrer, 2012).

En el año 1997, E. Ferrer y otros investigadores dan a conocer un lote de materiales de procedencia desconocida (colección Albelda) que podrían pertenecer a dragados posteriores al del año 1923, concretamente a otros trabajos en la ría bien fechados en 1925 y, por consiguiente, independientes del famoso depósito (Brandherm, 2007, 14). Estas labores se realizaron sobre una extensión de 20.000 $\mathrm{m}^{2}$ con el objeto de agotar el depósito exhumado dos años atrás. El inventario de las nuevas piezas es: dos espadas de lengua de carpa, dos puñales tipo Porto de Mós, una punta de lanza, tres regatones, dos hachas, un alfiler, dos colgantes amorcillados, cuatro fíbulas anulares y dos anzuelos. Los últimos materiales eran inéditos hasta esta última publicación (Ferrer et al., 1997).

Con bastantes reservas sobre su autenticidad, incluimos en este somero catálogo de piezas dragadas en aguas del Odiel un escarabeo de bronce que portaba la inscripción Neb-Maat-Rê de Amenofis III-Nebma'atre. El profesor García y Bellido (1970, 61-62, fot. 1-2) nos brinda la información de que entre los años 1928-1929 José Albelda regaló este amuleto a G. Bonsor. Las características del escarabeo han hecho dudar a los especialistas sobre su legitimidad: el peso $(0,75 \mathrm{~kg}$.), su tamaño cinco veces superior a lo habitual $(7,2 \times 5 \mathrm{~cm})$ al documentado en otros escarabeos, sus perfectas condiciones de conservación y la presencia de otro ejemplar idéntico en la colección de la familia Albelda, han llevado a cuestionar este testimonio y a valorarlo como una reproducción de los años veinte del siglo pasado (Ferrer, 1991). Con todo, recientemente se ha propuesto tomarlo de nuevo en consideración, aportándose algunos paralelos que podrían avalar su validez (Mederos, 2006, 169).

A todo este conjunto de materiales habría que añadir la punta de una espada de lengua de carpa, hallada de forma fortuita entre Matalascañas y Mazagón. Fue arrastrada por las redes de un pescador, aproximadamente a unas dos millas de la costa (Meijide, 1988, 113). 
Disponemos, en síntesis, de un inventario amplio de materiales arrojados a las aguas del estuario onubense que parecen certificar que esta desembocadura mantuvo un carácter sagrado y ritual que pervivió mucho más allá del Bronce Final. De hecho es fácil advertir como el propio depósito de bronces muestra un conjunto de piezas de diferentes épocas, algunas casi unas reliquias, lo que concuerda bien con la idea de un espacio ceremonial que a tenor del resto de objetos arrojados parece mantener a lo largo de varios siglos (figura 4). El lugar recuerda otros donde sucede algo semejante. Nos referimos a la desembocadura del Ulla, en torno a Catoira, en donde se localizaron también distintas armas entre la Isla de Cheta (Pontevedra) y la Isla dos Ratos (A Coruña). El período que abarca dichos materiales comprende desde finales del Bronce Medio hasta época moderna, con un hiato durante la Edad del Hierro. Este panorama se repite en el lugar de Porto, cercano a la desembocadura del Sar, con una secuencia temporal semejante (González Ruibal, 2006-2007, 123), y es conocido también en otras deposiciones de cronología posterior de la Europa nórdica y central (von Nicolai, 2012, 42-43).

II. LO QUE LAS AGUAS ESCONDEN: ¿PECIO O DEPÓSITO?

Con motivo del dragado del río Odiel a finales de marzo del año 1923, la draga Cinta de la Junta de Obras del Puerto de Huelva, del tipo de rosario, comenzó a extraer objetos de bronce mezclados con el fango del río y fragmentos de madera. Este hallazgo se produjo entre los 7,5 y los 9,5 m de profundidad, a $23 \mathrm{~m}$ al sur del muelle de la compañía minera Tharsis, en el lugar conocido como "Cabeza de Tharsis", según consta en el Boletín Oficial de la Provincia de Huelva ( $\mathrm{n}^{\mathrm{o}}$ 193, con fecha de 25 de octubre de 1923). Es decir, el depósito fue arrojado a las aguas en la mitad del antiguo cauce del Odiel, frente al hábitat protohistórico, en el extremo interior del antiguo golfo marino, en la frontera entre el río y el mar (Almagro Basch, 1940, 85; RuizGálvez, 1995a, 20).

Entre los meses de marzo y abril fueron extraídos del lecho del río hasta unos 400 objetos de bronce (número de piezas aproximado, pues es posible que algunas se encuentren todavía en manos de coleccionistas privados, fuera de control), entre equipo militar y elementos de vestuario. Sin embargo, en el inventario judicial publicado en el citado Boletín Oficial se refieren un total de 396 piezas por parte del juez instructor del expediente del hallazgo, D. Juan
B. Borer y Dotres. Según el informe de las obras remitido a la Real Academia de la Historia (Albelda, 1923), el estrato donde se hallaron los bronces estaba formado por arenas gruesas y conchas. El nivel superior era estéril y estaba compuesto por légamos. El inferior del depósito era también estéril, y su composición era de arcillas que alcanzaban bastante profundidad. Gómez Moreno apunta que el lugar donde yacía el conjunto de bronces estaba formado por "una delgada capa de arenas y conchas (...) teniendo encima fango de acarreo aluvial" (Gómez Moreno, 1923, 89). Un dato significativo es la referencia manuscrita de que junto al armamento fueran extraídas numerosas piedras, lo que hizo pensar en su momento en que formaran parte del lastre del barco hundido (Ferrer, 2012, 52, nota 18). Todas estas circunstancias proporcionaron una idea de coetaneidad y localización precisa del lote de bronces, lo que propició su interpretación como pecio, es decir, el cargamento de un barco hundido.

Hasta aquí llega la información disponible sobre las circunstancias y el contexto arqueológico del hallazgo. A pesar de las dificultades de interpretación que tales datos entrañan, conviene analizar algunos aspectos que tradicionalmente se han prestado demasiado al juego de la imaginación.

a) Podemos dar por sentado que el área de concentración del lote de bronces dragado fue relativamente reducida. Se deduce no solo de la descripción del ingeniero-subdirector de las Obras del Puerto y secretario de la Comisión de Monumentos de Huelva, don José Albelda (1923, 222), quien escribe al respecto lo siguiente: "siendo encontrados reunidos en una zona muy restringida"; o de los relatos que proporcionan otros autores como E. Díaz (1923, 37), quien refiere que tras el hallazgo de las primeras armas del depósito, "en días sucesivos y en el mismo lugar han ido saliendo espadas y más espadas”; sino también del hecho de que en el año 1925 se efectuó un amplio dragado de las zonas inmediatas al hallazgo con el objetivo de agotar el depósito, que afectaron a $20.000 \mathrm{~m}^{2}$ y $2 \mathrm{~m}$ más de profundidad, teniendo como resultado la recogida de muy pocas piezas, probablemente no atribuibles al conjunto de 1923 (Ferrer et al., 1997). En rigor no es esta una información que pueda ser tomada como argumento a favor o en contra de las diferentes hipótesis que se han vertido sobre la funcionalidad del hallazgo, pues el grado de concentración de los bronces se presta a múltiples posibilidades de lectura. Es más, a la hora de especular sobre el grado de concentración del de- 


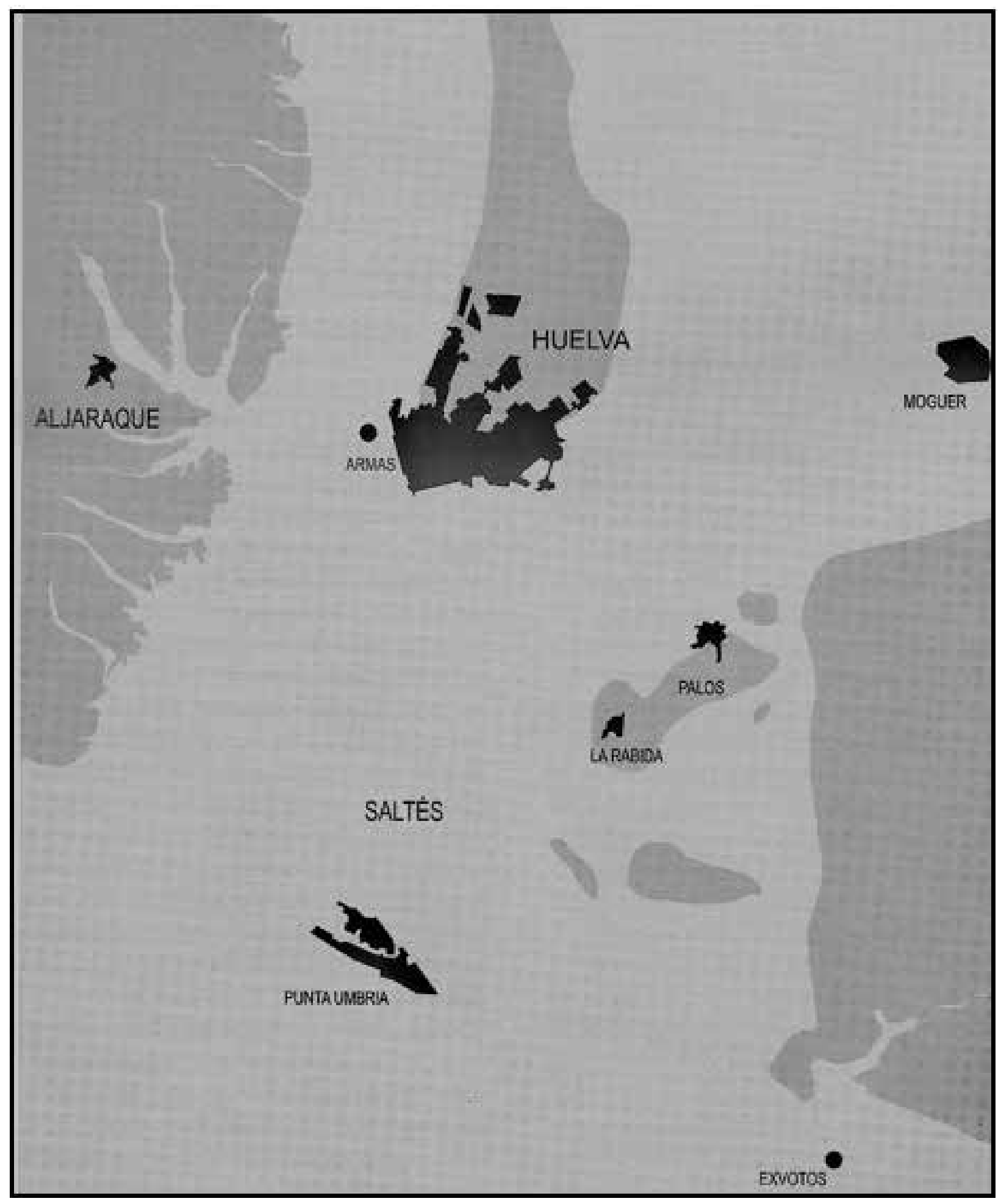

Figura 4. Estuario de los ríos Tinto y Odiel en la Protohistoria, con la situación del depósito de 1923 y otros objetos arrojados a sus aguas (Fernández Jurado, 2005, 743, figura 6). 
pósito tampoco conviene olvidar las observaciones que se han hecho sobre las características del tipo de draga que exhumó el lote de piezas metálicas y los restos de madera, pues las dragas de rosario suelen remover y arrastrar los materiales del fondo de los lechos de los ríos; o la probabilidad de que los materiales pudieran haber quedado concentrados y retenidos en pozas de la ría, arrastrados por la corriente hacia el mar (comunicación personal de Garrido Roiz a Ruiz-Gálvez, 1995a, 159).

b) La presencia de madera asociada a los bronces ha sido otro argumento utilizado para defender las diversas tesis sobre la funcionalidad y naturaleza del hallazgo fluvial. Ha sido valorada como posibles restos pertenecientes a una barcaza, a un embarcadero, a una plataforma desde donde arrojar los objetos metálicos, a los astiles de las lanzas, etc. Lo cierto es que esta madera ni se conservó ni fue analizada, más allá de algunos fragmentos de astiles que aparecieron en el interior de los enmangues de las lanzas, y fueron empleados para la obtención de cronologías absolutas. La única mención a "algunos vestigios de madera" en la bibliografía nos la proporciona por primera vez J. Terrero (1944), aunque se puede constatar también en el citado Boletín Oficial de la Provincia de Huelva ( $\mathrm{n}^{\mathrm{O}}$ 193) del 25 de octubre de 1923, donde se refiere concretamente el hallazgo de "cinco trozos de madera focilizada”. Como puede comprobarse, los testimonios son muy poco elocuentes y hacen difícil cualquier elucidación.

c) El baile de cifras sobre el número total de bronces dragados es otra constante en la bibliogra- fía. Podría decirse, incluso, que se establecen tantas cantidades que puede conducir a la confusión a quien no dedique algo de tiempo a realizar un balance correcto del depósito. En este sentido, según el inventario y estudio de Almagro (1958), completado años más tarde por Ruiz-Gálvez (1995a), el número total de objetos de bronce, completos o fragmentados, (con la excepción de un fragmento informe de hierro) recuperados del fondo de la ría de Huelva es de 413 en total, si bien quedan algunas dudas sobre otras pocas piezas (alfiler, hachas y colgantes amorcillados) sobre las que no se tiene la certeza de si fueron extraídas de las aguas en dragados posteriores (durante el año 1925) o junto con el resto del depósito en 1923 (Ferrer et al., 1997, 77). La composición de este importante depósito es la siguiente (Figura 5):

Como se puede observar en la tabla y gráfico posterior, del conjunto destacan particularmente las armas con 364 piezas completas o fragmentos entre espadas, puñales, lanzas y regatones, puntas de flecha y trozos pertenecientes a cascos. Se trata, en su mayor parte, de armas ofensivas: espadas, lanzas y puntas de flecha, con un predominio de las primeras $(26,9 \%)$. Es posible, incluso, que algunos de los fragmentos incluidos en el grupo de elementos indeterminados, concretamente tres placas de bronce, pudieran formar parte también de los cascos.

Llegados a este punto, parece conveniente examinar algunas características específicas sobre la composición del lote de armas y otros objetos, así como el estado en que fueron halladas algunas piezas, con el fin de plantear la posibilidad de que cier-

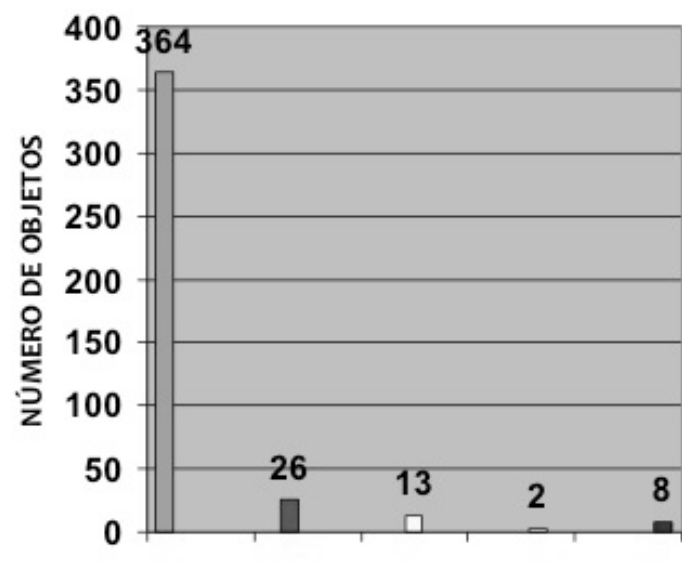

TIPOS

\begin{tabular}{|l|r|c|}
\hline TIPOS DE ARMAS & $\begin{array}{l}\text { No TOTAL } \\
\text { DE PIEZAS }\end{array}$ & $\%$ \\
\hline ARMAS & 364 & 88,1 \\
\hline VESTIMENTA & 26 & 6,2 \\
\hline ARREOS & 13 & 3,1 \\
\hline ÚTILES & 2 & 0,4 \\
\hline VARIOS & 8 & 1,9 \\
\hline ESPADAS & 98 & 26,9 \\
\hline PUÑALES & 30 & 8,2 \\
\hline LANZAS & 86 & 23,6 \\
\hline REGATONES & 67 & 18,4 \\
\hline PUNTAS DE FLECHA & 17 & 4,6 \\
\hline CASCOS & 9 & 2,4 \\
\hline
\end{tabular}

Figura 5. Distribución de objetos por tipos en el depósito de la ría de Huelva. 
tas armas fueran inutilizadas de forma intencionada o bien fueran armas de parada.

\section{1. El contenido}

De los 98 fragmentos o espadas completas dragadas en el depósito onubense -que según B. Quilliec se corresponden a 85 espadas, de las cuales 12 están intactas y el $90 \%$ presenta huellas de uso previas a su deposición acuática (Quilliec, 2007b, 47 y 103)el predomino morfológico corresponde al tipo de lengua de carpa con distintas variantes (Brandherm y Moskal-del Hoyo, 2010; Milcent, 2012, 126, Pl. 53), aunque no faltan otros ejemplares como las espadas de empuñadura maciza. Como dijimos, en el depósito onubense aparecen todas las variantes del tipo Huelva, salvo la variante Mouy. Desde el tipo más antiguo al más reciente, el recuento de ejemplares va en aumento (Cambes: 3 piezas; Marmolejo: 16 piezas; Oissel: 22 piezas), lo que parece sugerir, con bastante cautela, una sucesión en el ritmo de deposición (Brandherm y Moskal-del Hoyo, 2010, 436).

Un buen número de estas armas presentan evidentes huellas de uso y de deterioro (el 90\%), esto último debido también al tiempo que estuvieron expuestas en el fondo de la ría. Por otra parte, no faltan ejemplares (el 68,5\%) que presentan deformaciones, fracturas o muescas muy pronunciadas que invitan a pensar en una verosímil inutilización ritual (Quilliec, 2007b, 104). Nos referimos, entre otras, a la espada en lengua de carpa (sigla: 32.289-30.21.14) (Ruiz-Gálvez, 1995a, 188, lám. 4ª , $\mathrm{n}^{\mathrm{o}} 4$ ) con señales en su hoja de haber sido forzada; a la espada del mismo tipo (sigla: 32.295-36.53.24) (Ruiz-Gálvez, 1995a, 189, lám. 6ª , nº 5), cuya estrecha hoja fue doblada hacia la derecha; o a la espada (sigla: 32.267-8.51.27) (Ruiz-Gálvez, 1995a, 189, lám. $6^{\mathrm{a}}, \mathrm{n}^{\mathrm{o}}$ 6) cuya hoja fue retorcida hasta el remate, lo mismo que la punta, curvada hacia la derecha (figura 6). Según Quilliec, aquellas espadas que presentan huellas múltiples indican que estamos ante actos intencionados. La fragmentación sistemática de unas espadas en varios trozos representa algo más que el resultado de un combate. La repetición de impactos sobre una hoja, su doblado o torsión, como es el caso de algunos de los ejemplares de la ría de Huelva, son, probablemente, el resultado de actos premeditados. Estos gestos rituales pudieron ser realizados por diversos actores, tales como un guerrero, un especialista en el ritual o un broncista, lo que dotaría de más significado a la presencia en el depósito del cincel y el punzón, útiles asociados al trabajo del fundidor (Quilliec, 2007b, 105). La hipótesis encuentra un apoyo argumental en el estudio de algunos santuarios galos e ibéricos del nordeste peninsular, donde la amortización ritual de las armas (después de su exposición a la intemperie para iniciar la degradación del metal) parece que fue ejecutada por sacerdotesherreros con conocimientos metalúrgicos (Gracia, 2003, 57 y 128). En cualquier caso, aunque somos partidarios de mantener esta lectura ritual para las manipulaciones simbólicas de las armas, tampoco podemos perder de vista la posibilidad de que las melladuras sean el resultado de un uso efectivo o real de las espadas y en estos casos dichas muescas sean más marcas de honor que merma de valor del arma u otra cosa.

Por otra parte, la inutilización ritual de armas presenta un contexto más amplio a partir de otros depósitos meridionales: la espada Monte Sa Idda que fue exhumada en el Guadalquivir a la altura de Alcalá del Río apareció doblada; los dos cascos griegos recuperados en el río Guadalete y en la misma ría presentan igualmente señales de deterioro intencionado. El análisis metalográfico del casco corintio del Guadalete muestra que fue inutilizado mediante una perforación realizada de dentro a afuera. Justo es recordar que al otro casco griego recuperado en aguas onubenses le falta también un fragmento de la parte posterior.

Similares manipulaciones presentan otras muchas armas ofensivas y defensivas exhumadas en el depósito. Por lo que respecta a los puñales (la totalidad del conjunto pertenece al tipo de lengua de car$\mathrm{pa}$, en el que destacan algunos ejemplares Porto de Mós), además de las huellas de uso y reutilizaciones se percibe en determinadas piezas ciertas evidencias de deterioro. Más intencionalidad es observable en el lote de lanzas. En este conjunto contamos con puntas deformadas y con melladuras, curvadas o dobladas (sigla: 24/60/77-84.200) (Ruiz-Gálvez, 1995a, 202, lám. 12, no 11), con fracturas en la hoja (sigla: 32.371-118.128.196) (Ruiz-Gálvez, 1995a, 203, lám. 12, n⿳0 20), muescas, y en uno de los ejemplares una perforación en la base de la punta de lanza (sigla: 32.373-120.100.187) (Ruiz-Gálvez, 1995a, 206, lám. 14, $\mathrm{n}^{\mathrm{o}}$ 1). Así mismo, del conjunto de lanzas sobresalen tipos como el único ejemplar del tipo Vénat (sigla: 178), cuyo análisis metalográfico (una aleación ternaria) indica que la pieza parece haberse fundido en otro lugar distinto al del resto de bronces del depósito, quizás importada del centro de Portugal o de Peña Negra; la lanza calada de 
tipo británico con decoración (sigla: 32443.-140), que se corresponde con un prototipo conocido desde el Bronce Final II; o las lanzas de tipo "París", que nos informan de la adopción y el prestigio de ciertos modelos foráneos que tienen sus modelos en un momento anterior, aunque su probable fabricación haya que buscarla igualmente en el centro de Portugal o en el sureste peninsular (Ruiz-Gálvez, 1995a, 61-62; Milcent, 2012, 123). Sería interesante distinguir si estamos frente a armas importadas o se trata de imitaciones, ya que, como afirman $\mathrm{K}$. Kristiansen y T. B. Larsson $(2006,34)$, una imitación nos informa mejor sobre el valor local que se le otorga a los bienes de prestigio y al saber tecnológico foráneo, ya que representan unos elementos y un conocimiento exterior imbuido de estatus.

Cabe destacar también que los regatones cónicos con remate en botón y las puntas de flecha muestran señales de rotura ${ }^{1}$, a parecen doblados y deformados, $y$ al igual que en el caso expuesto de una de las lanzas, un regatón posee una perforación en el extremo superior (Ruiz-Gálvez, 1995a, 211, lám. 16, $\mathrm{n}^{\mathrm{o}}$ 15; Milcent, 2012, 125). Para finalizar con este breve recorrido por las armas recuperadas en el fondo de la ría, hay que mencionar que los restos de cascos encontrados (que responden a los tipos de cresta y cónico, algunos decorados con acanaladuras) aparecieron igualmente rotos y deformados. A pesar de que se les ha considerado tradicionalmente como importaciones -desde el estudio de Schauer (1983) se le ha asignado un origen asirio-urártico-, los análisis metalográficos no desentonan con el resto de los materiales del depósito. Así pues, tecnología y composición parecen ser bastante similares, incluso los oligoelementos son exactamente los mismos que el resto de las piezas analizadas (RuizGálvez, 1995a, 62), sugiriendo una fabricación local. Es más, cascos de crestas se conocen tanto en la Europa Central como en el ámbito atlántico desde principios del Bronce Final, con lo que la vía de introducción mediterránea puede ser cuestionada (Brandherm, 2011; Coffyn, 1985, 171-172).

Del resto de los bronces justo es destacar la presencia importante entre los elementos de monta de algunas piezas que podrían pertenecer a pasa-

1 Durante el Bronce Final, el registro de puntas de flecha en contextos domésticos disminuye de manera sensible, mientras que su presencia se incrementa en los depósitos (el $23 \%$ del total). El depósito de la ría de Huelva destaca por el número de piezas y la variedad de tipos representados (Kaiser, 2003).

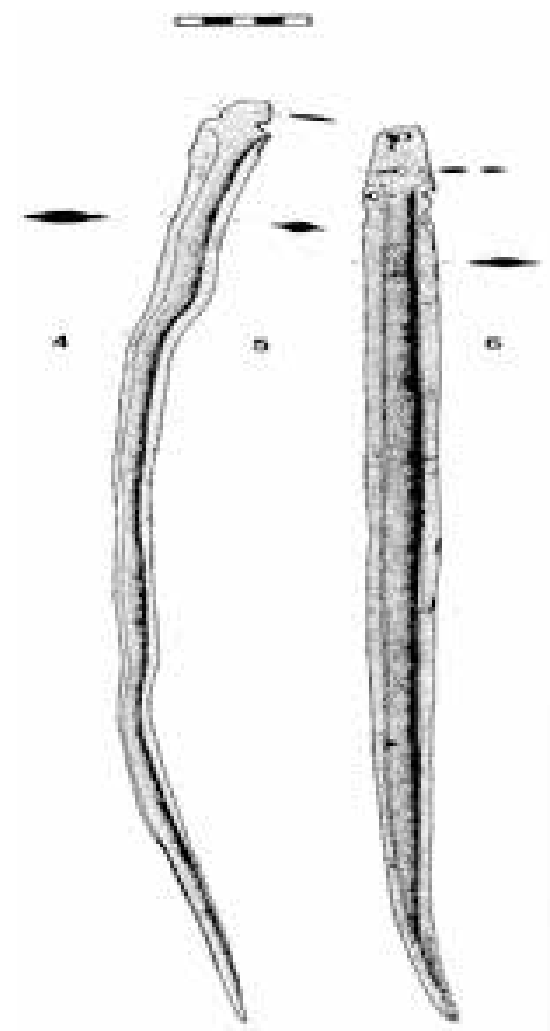

Figura 6. Espadas inutilizadas ritualmente pertenecientes al depósito de la ría de Huelva (según Ruiz- Gálvez, 1995a).

rriendas de caballos y carros (quizás combinados con materiales orgánicos), contribuyendo a dotar al depósito de una simbología cosmológica, votiva o funeraria aún mayor. Su asociación con los tipos de bronces del depósito, considerados como elementos identificativos de rango social, ha llevado a proponer que su presencia en las aguas de la ría de Huelva es indicativa en este caso del uso de carros, idea que podría contrastarse en la amplia difusión que tiene este vehículo en las representaciones de las estelas decoradas y el arte rupestre del suroeste (Ruiz-Gálvez, 1995a, 141; Harrison, 2004, 112-114), así como en el probable aguijón para caballos procedente del depósito de Nossa Senhora da Guía (Baiões, Portugal) o en el uso ritual o simbólico posterior, documentado en necrópolis como La Joya $u$ otras. Arneses de caballos no faltan tampoco en otros depósitos europeos del Bronce Final, como el de Isleham (Cambridgeshire, Inglaterra), en donde se combinan con diferentes tipos de armas, lo mismo que se observa en depósitos situados al norte de los Pirineos, o en las amortizaciones launacienses del sur de Francia (Brandherm, 2008-2009, 27). Sin 
embargo, D. Brandherm cuestiona en un reciente trabajo, la función como piezas de carro y arreos de caballo tradicionalmente atribuido a las anillas de bronce, dos anillas dobles y una anilla triple con barra presentes en el depósito onubense, pues por sus formas, tamaños y asociaciones con otros materiales, podrían haber sido destinadas a otros usos: como suspensión de espadas, palanca de balanza, etc. (Brandherm, 2008-2009).

En cuanto a las piezas pertenecientes a la indumentaria o vestimenta, parece pertinente mencionar por su condición de objetos de prestigio o estatus, las fíbulas de codo (una última revisión en Carrasco et al., 2012), los botones, los dos broches de cinturón de un garfio y las seis piezas de bronce identificadas tradicionalmente como torques con remates cónicos, aunque se ha puesto en duda tal identificación, pudiéndose tratar de elementos de aplique (Ruiz-Gálvez, 1995a, 225). En este apartado, sería interesante definir con precisión ante qué tipo de objetos estamos, puesto que los torques representan elementos de decoración de indudable valor étnico y estatus social, como puede certificarse en el mudo céltico. Estas piezas eran usadas por los dioses y los guerreros, y se les consideraba como símbolos de coraje. Así mismo, contamos con un conjunto de pasadores cilíndricos, entre los que destacan dos por aparecer soldados y deformados, quizás por haber estado sometidos a calor. Por lo que respecta a los botones de bronce, en el depósito onubense se recogieron piezas de tres tipos (clasificadas por algunos autores con las letras A, B y C). Se trata de elementos que durante el Bronce Final son comunes en otros depósitos peninsulares (como el de Cabezo de Araya) y europeos, en contextos de hábitat, y en menor medida en el ámbito funerario. Su función como elementos de vestir se ha cuestionado recientemente, proponiéndose una polifuncionalidad, entre la que su uso como piezas de arnés presenta sólidas posibilidades (Brandherm, 2008-2009, 29 ss.). En cualquier caso, como ya advirtiera Ruiz-Gálvez (1995a, 139-140), estamos ante complementos costosos y suntuarios de trajes, y además frente a nuevas formas de atuendo y arreglo corporal que comienzan a generalizarse quizás desde los siglos XI-X a.C. a tenor de la cronología asignada a algunos materiales procedentes de la tumba portuguesa de Roça do Casal do Meio. De este modo, disponemos de un repertorio de piezas de nuevas formas de vestido y cuidado estético y corporal repartidas por numerosos yacimientos $\mathrm{o}$ bien visibles en la misma iconografía de las estelas del suroeste, que representan una intensificación y una sexualización del cultivo corporal. El cuerpo adornado refuerza la figura de los jefes y ensalza los ideales masculinos.

Una mención aparte merecen el fragmento informe de hierro (sigla: 24/60/133.424) verificado entre los bronces del depósito, pues añade un lugar más al inventario de sitios con presencia o importaciones de este metal en un momento precolonial, y singulariza la metalurgia del hierro como otro aspecto exótico de gran prestigio e importancia social, así como los útiles de bronce exhumados y relacionados con el trabajo metalúrgico: un cincel plano de filo recto (sigla: 32.567.226), posiblemente empleado para labores de precisión como orfebrería o trabajo sobre chapa de bronce, un punzón biapuntado y algunas láminas amorfas de metal, posible material éste de desecho o restos de chatarra. El análisis metalográfico de estos útiles revela que el cincel, por ejemplo, fue usado para trabajar un material más blando que el bronce, quizás madera, oro o láminas de bronce, lo que convertiría a su dueño en un artesano especializado y explicaría su asociación al prestigioso conjunto de armas y elementos de vestido. A este respecto, hay estudios que han propuesto la posibilidad del uso del hierro, en forma de punzones, durante el Bronce Final en la decoración de objetos metálicos (cobre y bronce) (Harding, 2003, 230). Conviene tener presente también, que en los ajuares funerarios de jefatura de la Edad del Bronce de la Europa nórdica y central, se incluía un cincel para la talla de madera, convirtiéndose en una pieza diagnóstico de los jefes masculinos (Kristiansen y Larsson, 2006, 77). En cualquiera de los casos, en la actualidad es un hecho admitido que en la cadena de actos rituales que concluyeron con la cesura definitiva de los objetos en los depósitos, intervinieron de un modo u otro metalúrgicos (tanto en la selección de las ofrendas como en su diversa manipulación) (Lagarde y Pernot, 2009, 180).

Un breve resumen de los diversos estudios arqueometalúrgicos del depósito (Rovira, 1995, 56; Ruiz-Gálvez, 1995a, 59-67, 158; Montero et al., 2007; Gener et al., 2009)2 , permite establecer que estamos ante piezas de bronce de buena calidad, con tasas de estaño similares a otros conjuntos procedentes de depósitos británicos y franceses, pero más

2 Otros análisis tecnológicos de sumo interés en Hunt, 2001; Rovira, 2007; Montero et al., 2008. 
altas que la de los bronces mediterráneos, y un nivel bajo de impurezas. Tales peculiaridades plantean la posibilidad de que nuestro lote de bronces de la ría de Huelva haya sido fundido en algún taller ubicado en el suroeste peninsular y en fechas más o menos sincrónicas (aunque algunas piezas tengan prototipos foráneos y con mayor antigüedad), por lo cual quienes defiendan la hipótesis de que el depósito es la carga de un barco hundido deberán admitir que los bronces procedían de la región, o la embarcación partía de Huelva hacia otro destino. Por el contrario, aquellos que sostienen la tesis de que los bronces son el resultado de ofrendas votivas, deberemos admitir que los oferentes adquirieron dichas piezas en talleres de la propia zona. Otro dato más apunta hacia esta producción local: el patrón de impurezas de los bronces podría señalar bien un origen común de los minerales metalíferos de un área del entorno no identificada, o bien la posibilidad del uso sistemático de metal muy reciclado, lo cual, coincidiendo con la interpretación de Rovira, parece poco probable por cuestiones tecnológicas y de acceso en la región a unos recursos que haría innecesario el uso y la importación de chatarra o material de desecho. Por el contrario, los análisis de isótopos de plomo señalan diversas procedencias para el metal, relacionándolos con las regiones mineralizadas de Ossa Morena y Valle de Alcudia (Sierra Morena) y no con la Franja Pirítica, los recursos más próximos al lugar de deposición. Al decir de los especialistas, dicha distribución recuerda la de las estelas del suroeste, significativamente ausentes de la provincia de Huelva.

Obvio es decir que uno de los apartados más importantes es el de la cronología del depósito. Desde su mismo descubrimiento el hallazgo se convirtió en un referente temporal y cultural tanto para la prehistoria reciente de la Península Ibérica como para la del resto del continente europeo. El único punto en común de todas las dataciones que se han propuesto para los bronces es el de ubicarlos en la segunda mitad del II milenio a.C., durante el Bronce Final, aunque no faltan autores que ponen en cuarentena dicha cronología proyectándola hasta el Hierro Reciente (Escacena, 2000, 28-32). Fue una destacada publicación de M. Almagro-Gorbea la que dio a conocer las primeras dataciones absolutas obtenidas por $\mathrm{C}^{14}$ sobre seis muestras de madera procedentes de los astiles de las lanzas recuperadas (CSIC 202-207), que arrojaron fechas comprendidas entre el 880-850a.C (Almagro-Gorbea, 1977, 524-525). Casi dos décadas más tarde, Ruiz-Gálvez (1995a, 79-83) procede a la calibración dendrocronológica de dichas fechas absolutas, contrastando los resultados con sendos tests de igualdad de medios y de varianza, así como situándolas en un contexto más amplio de dataciones radiocarbónicas procedentes de otros depósitos y yacimientos peninsulares. Los resultados arrojaron que las fechas más probables se sitúan entre la segunda mitad y finales del siglo XI a.C. hasta la primera mitad del IX a.C. para las muestras CSIC 202, 203, 206 y 207, fines del siglo XI, X y mediados del IX a.C. para la muestra CSIC 205 y el siglo $\mathrm{X}$ a.C. para la muestra CSIC 204. Como las fechas calibradas oscilan entre el 976 y el 932 a.C., se propone el siglo X a.C. como la datación más aceptable y real para el conjunto de la ría de Huelva. Recientemente se ha retomado la calibración de las muestras a partir de una versión más actualizada del programa de calibración (Mederos, 2006, 169, tabla 1), aportando una ligera elevación y amplitud del intervalo probable respecto a los datos anteriores: $c a$. $997-925$ a.C. ${ }^{3}$.

Vistas las fechas calibradas no es difícil concluir en su homogeneidad, lo que permite plantear a su vez que el conjunto de bronces pudo ser arrojado a las aguas del Odiel en una deposición única o en el lapso de tiempo relativamente corto de un siglo (entre 1050-900 cal. a.C.; siglo X a.C.). Sin embargo, algunos investigadores han puesto en evidencia las fisuras de esta teórica y probable homogeneidad temporal, lo que implica sugestivas modificaciones tanto en la cronología general del depósito como en su naturaleza y significado. Así por ejemplo, dentro del lote de materiales contamos con algunas piezas que a tenor de sus paralelos o de dataciones calibradas procedentes de otros contextos arqueológicos, arrojan fechas más antiguas o más recientes. Ciertos ejemplares como una posible espada de espiga de tipo Rixheim-Monza puede datarse en el Bronce Final I, mientras que las lanzas de ojales y tipo París, así como las espadas de empuñadura maciza, corresponden desde el punto de vista tipológico al Bronce Final II. A. Mederos (2008b) eleva también las fechas de las espadas de tipo Huelva, hasta el siglo XII a.C. Por contra, las fíbulas de codo tipo Huelva admiten

3 Sea como fuere, nos movemos en unas fechas acordes a la cronología que ofrece el reciente hallazgo de cerámica del Subprotogeométrico I/II en el casco de Huelva, fechada en torno al siglo X cal a.C.; según el estudio de esta cerámica griega y su influencia en la llamada cerámica tipo Carambolo, D. Brandherm data el inicio del hábitat indígena del Cabezo de San Pedro en pleno siglo X a.C. (Brandherm, 2008, 101 ss). 
fechas cronotipológicas y también radiocarbónicas del siglo IX a.C., y si se pudieran llegar a vincular las fíbulas anulares al dragado de 1923, tendríamos que admitir una cronología post quem todavía más baja, entre el siglo VI a.C. y el V a.C., teniendo en cuenta que el tipo de fíbulas de la ría pertenece a la variedad de "puente de cinta" (Escacena, 2000, 31; Cuadrado, 1969). Todo ello obligaría a reconocer la posibilidad de una perduración de piezas antiguas y la deposición de tales "objetos con biografía" en un lote de artefactos homogéneo arrojado a las aguas; o bien la contingencia de que el depósito se pudo ir acumulando a lo largo de los siglos (XI-IX a.C.), un hecho votivo de larga duración que se conoce bien en otros ríos europeos y peninsulares (Brandherm, 2007, 27).

\section{UN LUGAR DE MEMORIA}

En definitiva, ¿cuándo y cómo se produjo la deposición de todos esos objetos?; ¿en uno o en varios momentos?; ¿cómo se marcó el lugar?; ¿se arrojaron desde una embarcación o se hundió dicho barco? Difíciles preguntas para respuestas imposibles.

Una de las posibilidades sería a través de una plataforma o estructura de madera, remozada obviamente a lo largo del tiempo; otra, a través de algún tipo de marca o referencia visual desde tierra (situada a tan sólo $23 \mathrm{~m}$ de distancia), frente a la confluencia de los ríos Odiel y Tinto, y frente al hábitat protohistórico ${ }^{4}$. De esta forma, los bronces fueron depositados paulatinamente en el lecho fluvial, con un momento de máxima deposición durante el siglo $\mathrm{X}$ a.C. Se comprueba con facilidad la persistencia de un paisaje sagrado a lo largo del tiempo en la zona. La deposición continua en el tiempo no desentona con los materiales (y sus cronologías) exhumados en distintos puntos del estuario onubense, lo que parece reforzar la idea del carácter votivo de tales piezas y la naturaleza sagrada de la antigua desembocadura de Onuba. Así pues, la acumulación de deposiciones rituales, algunas de cierta antigüedad, unida al propio marco natural (una zona liminal, a caballo entre los ríos y el mar) debieron desempeñar un papel importante en la construcción del paisaje sagrado del estuario onubense. En este sentido, resulta interesante considerar la reciente propuesta de Alice V. M. Samson (2006) -formulada a partir de un análisis de hallazgos encontrados en el Mar del

4 Un factor a tener en cuenta en relación a la distancia de los bronces con respecto a la orilla, son los distintos coeficientes de las mareas en cada pleamar y bajamar, aspecto que analiza Fernández Jurado, 2005, 739.
Norte y en el Canal de La Mancha- que defiende la idea de considerar a las aguas marinas como lugares de deposición votiva, con el mismo rango que otras deposiciones fluviales y terrestres. La autora argumenta que el mar y este tipo de amortizaciones estaban incorporados a la cosmología de la Edad del Bronce, de un modo similar al que lo estaban otros lugares del paisaje (Figura 4).

Visto lo que antecede parece claro que nuestro objetivo hasta aquí ha sido el de registrar todos los indicios posibles del comportamiento técnico, ritual y del pensamiento religioso que pueden detectarse a través del conjunto de bronces depositados en el Odiel. En otras palabras, hemos observado si en la disposición de los materiales, su contexto de aparición, la elección de las piezas o su posición, hay evidencias que permitan adivinar un dispositivo intencional, lo que nos introduce de lleno en los posibles significados del hallazgo. Cuatro han sido las hipótesis que la investigación ha manejado a la hora de explicar la presencia de este lote de bronces en las aguas de la ría. Siguiendo un orden cronológico, la primera y con mayor peso historiográfico, es la que desde el mismo descubrimiento hasta la actualidad lo interpreta como un pecio, es decir, el cargamento de un barco hundido que transportaba chatarra. La segunda, lo ha considerado como un depósito de fundidor hallado en una zona que posteriormente fue inundada por las aguas. La tercera marcó una ruptura importante con respecto a las anteriores, al valorar el depósito y sus materiales como ajuares funerarios de la necrópolis indígena de la Onuba prerromana, estableciendo así un vínculo entre el yacimiento, el resto de deposiciones de espadas aisladas o formando conjuntos del suroeste peninsular y las tradiciones rituales funerarias y mitológicas indoeuropeas documentadas en las regiones atlánticas europeas y las Islas Británicas durante la Edad del Bronce, así como en las posteriores comunidades celtas. Y, por último, la propuesta más reciente que argumenta que el depósito es el resultado de ofrendas votivas, funerarias o no. Como ya planteábamos, la fragilidad de todas las hipótesis es la nota dominante, puesto que la recuperación de los materiales se realizó sin ningún tipo de control arqueológico, no ha existido ni existe una auténtica arqueología fluvial y, además, la fuerza de la tradición y la autoridad académica paralizó durante bastante tiempo la imaginación científica. Por ello, no nos parece procedente rechazar en bloque ninguna interpretación, analizando cada una de las propues- 
tas que se han ofrecido para sopesar sus argumentos y que puedan ser debidamente contrastados.

\section{1}

El depósito como pecio: desde su descubrimiento es el planteamiento más invocado y el más tradicional. Los materiales y la madera son interpretados como los restos de un barco hundido que transportaba chatarra o material metálico para reciclar. La hipótesis se basa en:

a) Como ya se ha comentado, los objetos metálicos del depósito se fundieron en una misma región, probablemente en el mismo suroeste peninsular, tal y como se deduce de la homogeneidad de las aleaciones. Esto podría indicar que se tratara de un barco que transportaba chatarra local procedente de aquel ámbito geográfico y que se hundiera al salir del puerto. El carácter geoestratégico de Huelva jugaría a favor de este argumento (Ruiz-Gálvez, 1995a, 159). La diversidad de procedencias, incluyendo metales sardos, reforzaría también la hipótesis.

b) En el conjunto de bronces destaca la presencia de útiles relacionados con el trabajo del fundidor, así como fragmentos de metal: un punzón biapuntado, un cincel, una gruesa lámina de metal, posible material de desecho (cobre y bronce) y un fragmento amorfo de hierro, objetos que reforzarían la condición de chatarra o material para el reciclado del depósito.

c) Junto a los útiles y fragmentos metálicos asociados al trabajo del fundidor, muchas de las piezas, sobre todo las espadas, lanzas, regatones y cascos, aparecieron rotas. Según R. Bradley, el 60\% de las piezas están fragmentadas. Esta circunstancia podría deberse a la consideración de los objetos como chatarra. Es más, algunas armas como las espadas, las puntas de lanzas y los puñales presentan pesos relativamente regulares (las espadas $=325-380$ gr.; puntas de lanza y puñales=162,5 y 170 gr.; puntas de flecha=160 gr., la mitad del peso de las espadas aproximadamente), lo que podría apuntar al transporte de las armas fragmentadas como "barras" metálicas de bronce para facilitar su intercambio (Bradley, 2005, 159-160; Mederos, 2006, 168).

d) Los restos de madera se atribuyen a una embarcación. Recientemente se ha propuesto la posibilidad de que dicho barco sea más bien una barcaza con quilla plana, característica de las embarcaciones de la fachada atlántica europea, como el barco del Bronce Final de Dover, que estuviese transportando objetos de bronce para reciclar a una embarcación de mayores dimensiones fondeada frente a Huelva (Mederos, 2006, 168-169).

e) La descripción del contexto arqueológico del hallazgo, encontrado a bastante profundidad y sellado entre una capa de aluviones modernos por arriba y otra de arcilla estéril abajo, dentro de un perímetro relativamente reducido, indica la contemporaneidad de la deposición fluvial y, por consiguiente, la posibilidad de que se trate del hundimiento y el cargamento de un barco.

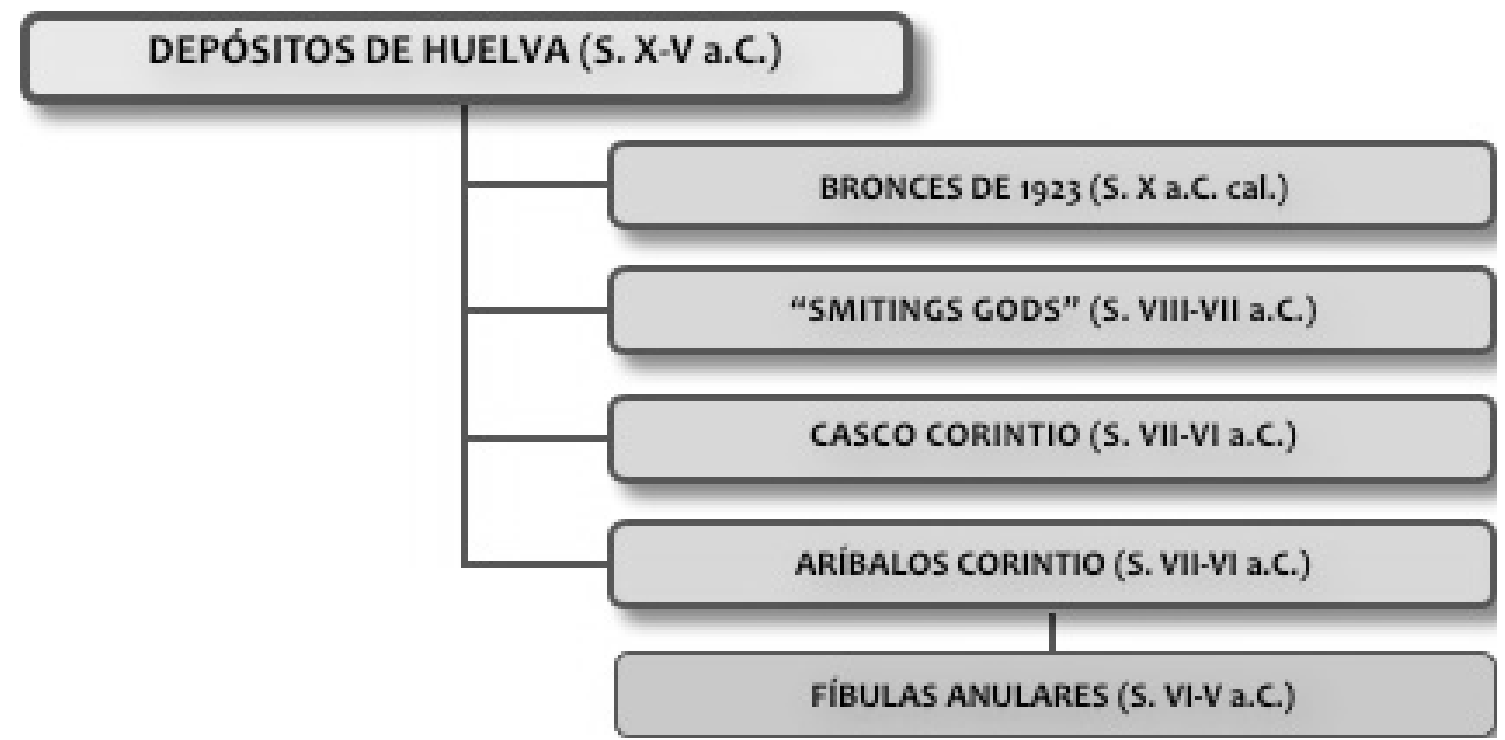

Figura 7. Cronología general de los hallazgos encontrados en la ría de Huelva. 
f) La distancia desde el lugar donde los bronces fueron dragados hasta la paleocosta hace difícil aceptar la posibilidad de que el depósito fuera arrojado de un modo intencionado o ritual a las aguas desde alguna estructura en tierra firme (Ruiz-Gálvez, 1995a, 159).

\section{III.2.}

Los bronces como depósito de fundidor: la idea fue expuesta por Díaz $(1923,40)$ sin encontrar eco alguno en la bibliografía posterior. Como ya se comentó, los bronces formarían parte de un depósito de fundidor situado en una zona que posteriormente fue inundada por las aguas. Esta consideración del depósito está en sintonía con la primera hipótesis al valorar el lote de metales como chatarra o material para el reciclaje, pues en su momento tanto el estado de los bronces como la presencia de objetos asociados al trabajo del fundidor, junto a fragmentos informes de cobre, bronce y hierro, encaminaban cualquier interpretación en esa dirección. Así mismo, no faltan tampoco lecturas recientes que explican como pérdidas accidentales o casuales, debido a las inundaciones, ciertos depósitos hallados en algunos ríos y lugares húmedos europeos. Así, en los asentamientos del Bronce Final de los lagos suizos se han encontrado grandes cantidades de objetos de metal en estos espacios acuáticos. Hasta hace poco se pensaba que eran el resultado de pérdidas naturales, restos de la vida diaria, o las consecuencias de inundaciones en las que la gente no pudo salvar sus pertenencias (Harding, 2003, 323; Testart, 2012). Los problemas que suscita esta interpretación son que la actual reconstrucción paleotopográfica del estuario onubense no certifica por ahora la posibilidad de que el lugar del hallazgo estuviera en su momento en tierra firme, más bien la delimitación de la antigua línea de costa plantea que el depósito se encontraba a unos $23 \mathrm{~m}$ de distancia aproximadamente de ésta, en pleno cauce fluvial. Del mismo modo, ya hemos comentado en la primera de las hipótesis analizadas, las dificultades para definir a este conjunto de bronces como un depósito de fundidor. $\mathrm{Y}$, por último, los argumentos que avalan las restantes interpretaciones resultan mucho más sólidos.

III.3.

El depósito como necrópolis indígena: es la hipótesis sostenida fundamentalmente por los profesores J.L. Escacena y M. Belén en numerosos trabajos. Para estos autores la aparente ausencia de enterramientos durante el Bronce Final en el suroeste peninsular (paralela a la inexistencia de hábitats) y en gran parte de la fachada atlántica europea se produce de forma sincrónica al surgimiento de los depósitos de armas en medios acuáticos, lo que sugiere que los cadáveres pudieron haberse arrojado a los ríos y lagos quemados o no previamente ${ }^{5}$. Esta costumbre funeraria se mantendría en Andalucía occidental hasta época romana, asociada a las poblaciones turdetanas, y quizás también a la de los túrdulos de la Baja Extremadura $\mathrm{y}$ a algunas comunidades del sur portugués. Se trataría, en suma, de una tradición indoeuropea precelta vinculada a las comunidades del Bronce Atlántico. De paso, la hipótesis sirve a los investigadores para argumentar su teoría sobre el carácter fenicio o mestizo de los enterrados en las tumbas de las necrópolis tartesias del orientalizante. Justo es decir que la propuesta es muy sugestiva y representa un camino de indagación a seguir. Es más, cuenta con paralelos coetáneos en regiones inglesas como la del Támesis, el río Walbrook y en algunos pantanos escoceses (Bradley y Gordon, 1988; Alfayé, 2009, 308-309); se ha defendido igualmente para otras regiones peninsulares como el noroeste (González Ruibal, 2006-2007, 119 ss.); dispone de ejemplos etnográficos bien conocidos, como es el caso de la India, con un refrendo imaginario en las mitologías indoeuropeas y leyendas medievales, como la de la "Muerte de Arturo", con la constante asociación arqueológica (ni mucho menos exclusiva) durante la protohistoria peninsular de las armas a los contextos funerarios (Belén y Escacena, 1995, 110), y, por último, con la vinculación documentada de lugares de enterramiento a puntos de paso estratégicos. Esta lectura es la que se ha otorgado a algunos depósitos gallegos, como el documentado en San Esteban del Río Sil (Orense), compuesto por una espada, dos lanzas y un anillo de nariz, considerado como el ajuar funerario de un guerrero de hacia el 1100 a.C. (Almagro-Gorbea, 2009, 52).

5 Los datos disponibles sobre las primeras cremaciones en el occidente peninsular indican que hacia el 1112-1066 a.C. ya se practicaba el rito, según las fechas obtenidas en la necrópolis de Paranho (Viseu, Beira Alta). No obstante, tenemos algunas fechas más antiguas aportadas por la necrópolis de Herrerías (Guadalajara). La datación de sus cistas arroja una cronología del 1225-1150 a.C. (Mederos, 2008, 64-65). Disponemos también de dataciones radiocarbónicas para alguna de estas cremaciones en el suroeste andaluz. Concretamente, para una registrada como reutilización en el Dolmen de Palacio III (Almadén de la Plata, Sevilla), arrojando una fecha de c. 940-760 a.C. y, por consiguiente, convirtiéndola en una de las cremaciones más antiguas fechada por radiocarbono en la Prehistoria Reciente del suroeste (García Sanjuán, 2005, 598-599). 
Sin embargo, a esta hipótesis de trabajo se le pueden poner, al menos, tres serias objeciones. La primera es que con la información disponible en la actualidad (tanto en lo que se refiere al poblamiento durante el Bronce Final en el suroeste, como en lo relativo a los espacios funerarios), el vacío de tumbas planteado para este período por los autores es cuestionable. A este respecto, el registro arqueológico disponible invita a plantear, por un lado, una cierta invisibilidad arqueológica asociada a poblaciones móviles con una economía en la que la ganadería tiene un gran peso, y a grupos que a tenor de la iconografía de las estelas y de las características de los depósitos votivos, manifiestan una ética o valores militares de tipo agonísticos, lo que pudo traducirse en prácticas de enterramiento tales como la exposición de los cadáveres a la intemperie. Por otra parte, puede hablarse también de una evidente diversificación funeraria que llevaría a estas sociedades protohistóricas al empleo de diferentes y concretos lugares mortuorios, tales como las propias viviendas o chozas, algunas cuevas o la reutilización de sepulturas antiguas o prehistóricas, tal y como en distintos trabajos viene argumentando desde hace algún tiempo L. García Sanjuán, y se tiene constancia fehaciente en el sureste peninsular. La falta de un peritaje arqueológico más preciso de todas estas tumbas mantiene aún la polémica abierta (Belén et al., 1991).

La segunda objeción que podemos plantear es la de la ausencia de restos óseos humanos en el depósito onubense, si bien la falta de todo control en los trabajos de recuperación de los bronces y las propias inquietudes científicas de la época podría justificar esta ausencia. Por otro lado, si los cuerpos arrojados al río Odiel hubieran sido cremados previamente en otro lugar, y desde hace bastantes años se viene defendiendo con argumentos convincentes la idea de la introducción de la cremación en la Península Ibérica durante el Bronce Final, el registro de las esquirlas óseas calcinadas mezcladas con el limo y otros materiales del lecho fluvial hubiera hecho casi imposible su identificación.

El tercer y último problema es que a pesar de las singularidades comentadas que presenta el hallazgo de la ría, tanto su contexto arqueológico como sus características y composición, son muy similares a las de otros depósitos votivos bien estudiados en el occidente peninsular y en el resto del continente europeo.
III.4.

El depósito como ofrendas votivas: este significado ha sido defendido principalmente por RuizGálvez, quien en diversos artículos y monografías (Ruiz-Gálvez, 1995a, 1995b, 1998) ha explicado con datos rigurosos y en profundidad el carácter votivo, funerario o no, del depósito. A pesar de que una buena parte de la investigación siga estando remisa a aceptar este tipo de lectura, en la actualidad constituye la alternativa científica a la idea del hallazgo del Odiel como pecio, recibiendo la sanción de una parte de la comunidad científica internacional (Bradley, 2005, 161). Sus argumentos son los siguientes:

a) La composición binaria de los bronces parece indicar que todas las piezas se fundieron en una misma región. Este hecho no encaja bien con las características y los materiales heterogéneos documentados en conocidos pecios del Mediterráneo como Uluburum, Kfar Samir y costa de Haifa, Punta Iria o Gelindoya (Ruiz-Gálvez, 1995a, 130; RuizGálvez, 2005, 256-260; Martín Ruiz, 2010). Se trata de cargamentos, como el de los barcos de Gelindoya y Kfar Samir, destinados al comercio de chatarra y refundición, y en el polo opuesto el de Uluburum con sus valiosas mercancías. En cualquier caso, su análisis permite afirmar que presentan características y finalidades muy distantes a la del conjunto de bronces recuperados en la ría de Huelva.

b) Diferencias similares en la composición de las piezas pueden plantearse entre un depósito de carácter votivo como el onubense y otro "depósito de metalúrgico o de fundidor" como el de Baioes, por ejemplo (Ruiz-Gálvez, 1995a, 131).

c) El hecho de que los materiales hayan sido removidos por una draga del tipo "de rosario" y el desconocimiento de la estructura geológica de la ría, impiden saber con precisión si las piezas se encontraban en un perímetro delimitado, como cabría esperar si se tratase del cargamento de un barco hundido. Las mismas razones que se esgrimen para justificar el hallazgo como un pecio podrían emplearse para defender su naturaleza intencionada y votiva. Es decir, la contemporaneidad del conjunto y su concentración espacial pueden ser consideradas igualmente como el resultado de arrojar de forma voluntaria las armas a las aguas desde una embarcación, plataforma o cualquier otro tipo de estructura. La distancia desde el depósito hasta la antigua costa onubense podría reforzar en este contexto la idea de una deposición ritual. 
d) Desde el punto de vista simbólico y social, el conjunto de bronces es muy homogéneo y selectivo, salvo nueve piezas (un punzón biapuntado, un cincel, una gruesa lámina de metal, posible material de desecho y un fragmento amorfo de hierro) cuya presencia puede ser coherente dentro del lote de armas, arreos y elementos de vestido y adorno. Estamos ante un depósito con objetos que son indicadores de un estatus social aristocrático y heroico, aspecto muy similar a los elementos representados en las estelas decoradas del suroeste o en algunos ajuares de la necrópolis orientalizante de La Joya.

La presencia de los útiles de fundidor y el material de desecho podría explicarse en función del rol social prestigioso y temido que parecen poseer los metalúrgicos como demiurgos durante la protohistoria. Su asociación al lote de armas es coherente teniendo en cuenta que estamos ante un conocimiento y unas técnicas especializadas que permiten resaltar durante la Edad del Bronce y del Hierro el estatus destacado de las élites. Por otra parte, caben otras valoraciones para estas piezas: el ajuar funerario de dicho metalúrgico o fundidor, la intervención ritual de un broncista en la ofrenda votiva de las armas, o bien que se trate simplemente de los dones sagrados entregados a una divinidad que tuviera relación con la actividad metalúrgica y con las aguas.

e) La fragmentación y el deterioro de una buena parte de los objetos metálicos podría obedecer a una inutilización ritual o voluntaria con el fin de impedir su reutilización. Los análisis efectuados recientemente por B. Quilliec (2007a; 2007b) sobre algunas espadas del depósito de Huelva apuntan en este sentido. Dicha explicación encaja perfectamente, además, con el estado en el que se hallaron otras armas depositadas en aguas peninsulares y británicas. La misma destrucción ritual parece que se produjo también en otros depósitos europeos.

La probable inutilización ritual (filos mellados, hojas dobladas, alguna pieza quemada, etc.) puede ser considerada, con prudencia, como otro indicador más del carácter votivo del depósito. Hoy por hoy, los análisis de las espadas y otros ítems amortizados despejan cualquier duda acerca de la existencia de unos patrones de destrucción intencionada en muchos conjuntos, entre ellos el de la ría de Huelva. Sin embargo, los motivos que pueden haber ocasionado la fragmentación de este material siguen suscitando múltiples hipótesis explicativas, polarizándose la discusión, en esencia, entre los especialistas que atribuyen motivaciones estrictamente profanas y aquellos otros que desarrollan lecturas de carácter ritual (Brandherm, 2007, 8). Entre los primeros predomina la idea que defiende que tales destrucciones son el resultado de que la chatarra debe ser reducida a trozos y muchas veces doblada para su reciclaje en un crisol de tamaño reducido. Estaríamos, en pocas palabras, ante depósitos de chatarra o de fundidor. Por otro lado, hay que tener muy presente otros motivos técnicos: los estudios metalográficos revelan en algunas armas onubenses defectos de fundición por la formación de burbujas que provocarían la rotura de la espada (Montero et al., 2002, 23).

Entre los segundos, se impone el argumento de la destrucción ritual de los objetos en los depósitos votivos, esgrimiéndose incluso teorías muy sugestivas como la que argumenta Louis Nebelsick (2000) acerca de los motivos extáticos de carácter dionisíaco como fundamento de tales destrucciones de carácter salvaje, o sin sistema. De hecho, se conocen bien los eufóricos festines de algunas poblaciones célticas tras concluir un combate decisivo o un período bélico, consistentes en la organización de sacrificios y banquetes redistribuidores de la riqueza capturada, dedicados al dios de la guerra en agradecimiento por la ayuda prestada (César, $B G$, $6,17,2-3)$.

Sea como fuere, las hipótesis no sólo no son excluyentes, sino que podrían traerse a colación algunas más, perfectamente compatibles con la naturaleza de los depósitos y sus contextos arqueológicos. Así, la fragmentación o destrucción podría ser el resultado del empleo de las espadas, por ejemplo, en combates reales; las piezas podrían haber sido objeto de una inutilización debido al carácter funerario de las ofrendas, o bien tales patrones de destrucción podrían responder a los ritos que se siguen en los spolia (Gabaldón, 2004). En este mismo sentido, otra de las posibilidades interpretativas de los depósitos múltiples de armas es que pudieran representar un rito destructivo vinculado al ámbito del sacrificio y de la guerra, asociado a la consagración del botín por medio de su destrucción (Gabaldón, 2001 y 2004, 24, nota 13). Es lo que algunos analistas designan con los términos "great votive deposits of weapons" o "booty sacrifice deposits": depósitos de botín. De hecho, en la actualidad es posible afirmar que la mayoría de las piezas de armamento antiguas descubiertas no son los restos de un combate propiamente dicho, sino el resultado de sus consecuencias 
inmediatamente posteriores, pues reflejan el saqueo y el pillaje por parte de los vencedores (Quesada et $a l ., 2010)$. Se trata de una exhibición de victoria, es decir, un amontonamiento de armas o trofeo, construido con armas enemigas tras una batalla y expuestas en un lugar sagrado de distintas formas. En este punto, habría que recordar algunas de las interpretaciones iniciales conferidas al conjunto de bronces onubense, como la tesis de Gómez Moreno (1923), quien apoyándose en la homogeneidad del lote, mellas de uso y reparaciones en las espadas, con ausencia de hachas y otros útiles, apuntó la posibilidad de que los objetos procedieran de "un campo de batalla"6; o la de J. M. Carriazo (1947, 798), quien sugirió la alternativa de que el lote estuviera destinado "a las gentes de guerra", pues aunque las señales de uso eran evidentes "los bronces no están muy oxidados, las espadas conservan sus filos y, a veces, la punta; las fíbulas pueden usarse todavía...”.

f) La comentada homogeneidad de los pesos, detectada en algunas armas (espadas, puñales y puntas de lanza), podría quedar explicada de forma satisfactoria si tenemos en cuenta la posibilidad de que el conjunto hubiera sido fundido en un mismo taller del suroeste peninsular: aleaciones, técnicas, moldes, pesos, etc., siendo en ese caso regulares.

g) Algunas de las lanzas conservaban una pequeña parte del astil de madera, lo que muestra que fueron arrojadas a las aguas enmangadas, reforzando así el carácter intencionado de la deposición, pues de lo contrario hubiesen flotado el tiempo suficiente como para poder ser recuperadas en el caso de un naufragio. O se les hubiese llevado la corriente (Belén en Ruiz-Gálvez, 1995a, 159).

h) Aunque las fechas de $\mathrm{C}^{14} \mathrm{y}$ calibradas, arrojen fechas homogéneas para el conjunto, que lo situarían a lo largo del siglo $\mathrm{X}$ a.C., pese a que hay materiales que presentan tipologías más arcaicas, ello no prueba en rigor que estemos ante el cargamento de un barco hundido. Durante poco más de un siglo o de un modo coetáneo, los bronces pudieron ser arrojados ritual y reiteradamente a las aguas del Odiel.

i) Los restos de madera encontrados junto con el fango y el resto de los materiales no tienen porqué pertenecer necesariamente al casco de un barco.

6 En un artículo reciente (Jantzen et al., 2011), se ha planteado la posibilidad de que los esqueletos, los huesos de caballos y las armas halladas en el lecho del río Tollense, en el nordeste de Alemania, fueran los restos de una batalla acontecida en la Edad del Bronce.
Sin descartar que fuera así, como sugerimos líneas más abajo, estos restos lígneos pueden tener otras posibles lecturas a tenor de lo documentado en distintos depósitos y yacimientos del Bronce europeo y peninsular, o a partir de algunas prácticas rituales atestiguadas en el ámbito céltico, nórdico o griego. Así pues, la madera podría pertenecer también a un embarcadero, a una calzada que permitiría deslizar las embarcaciones hacia y desde la playa, a una plataforma desde donde arrojar los objetos, bien atestiguada en Flag Flen, Port (Nidau-Büren), East Sussex, o en el sitio de La Têne (Harding, 2003, 327 , nota 125); ser parte de las mismas armas, o bien tratarse de los vestigios de una embarcación hundida ritualmente con los bronces ${ }^{7}$.

En relación con esta última hipótesis, es posible conciliar la interpretación de los restos de madera como pecio, es decir, que pudieran pertenecer a un barco, y según nuestra sugerencia a una embarcación ritual, con el verosímil uso del supuesto barco y su contenido como ofrenda ritual a las aguas. $\mathrm{Di}-$ cha práctica casa bien con la lectura económica y social atribuida a algunas deposiciones de bronces: un potlach. De hecho, asociadas a un posible lugar de culto excavado en la calle Méndez Núñez 7-13 esquina con la plaza de las Monjas, fueron hallados varias placas y clavos de hierros usados en el armazón de un barco, al igual que cuadernas de madera (González de Canales et al., 2004). A este respecto hay que tener en cuenta que la construcción de un barco representa una inversión de tiempo, de recursos y de conocimientos bastante considerable, $y$, por consiguiente, su amortización final en este tipo de prácticas deposicionales por parte de los linajes principales puede equipararse a la ofrenda a las aguas de otras piezas de indudable valor emblemático, práctico y religioso, tales como las armas, elementos de vestido, arreos de caballo o los restos de carros. No hace falta hacer hincapié en el hecho de que poco tiempo después estos mismos elementos quedarán depositados como ajuar funerario en el interior de las tumbas orientalizantes tartesias. Como refuerzo de esta argumentación, podríamos

7 Sin que, en rigor, puedan descartarse otras posibilidades, tales como que algunas de las piezas arrojadas al fondo del estuario onubense estuviesen contenidas en una o varias cajas de madera. De hecho, esta hipótesis se ha formulado para los materiales recuperados en los depósitos de Samieira (Pontevedra) o La Morterona (Palencia), donde se han conservado grandes trozos de carbón vegetal; Delibes et al., $2007,340$. 
traer a colación la participación de barcos (reales o en forma de pequeños objetos) en los rituales acuáticos célticos y escandinavos, que cuenta con evidencias arqueológicas contundentes como Hjortspring (Dinamarca), Nydam (Schleswig-Holstein) (Gabaldón, 2001, 95; Jensen, 2012; von Nicolai, 2012, 45; Testart, 2012, 373-374) o el estuario de Óbidos (Portugal), donde fue recuperado también restos de un muelle de madera que González Ruibal (2006-2007, 123, 126) adscribe a la Edad del Bronce. La literatura clásica nos informa igualmente de la realización de ofrendas acuáticas de embarcaciones por diferentes motivos, como ilustra Tucídides (II, 92, 4-5).

j) La propia localización práctica y simbólica de los bronces en zona de estuario queda bien contextualizada respecto a otros depósitos votivos documentados fehacientemente en desembocaduras del suroeste peninsular y del resto de la fachada atlántica europea, sin olvidar los restantes hallazgos exhumados a lo largo de los años en la desembocadura conjunta del Tinto/Odiel. A este respecto conviene recordar, además, el carácter sagrado que poseen las aguas marinas, las zonas de desembocaduras y las confluencias fluviales o de ríos y el mar, así como los vados. Y que muchos de los hallazgos metálicos en los ríos del sur peninsular no proceden de tramos navegables.

k) Todavía podemos invocar un argumento más en favor de la interpretación como depósito votivo de los bronces onubenses. Nos referimos a la lectura polisémica y simbólica de los materiales incluidos en el conjunto. Incluso, algunos de los bronces de prestigio dragados en la ría poseen una proyección religiosa posterior. En primer término habría que singularizar el fragmento informe de hierro hallado entre los distintos objetos de bronce del depósito, pues se trata de un material importado en el conjunto, que ha podido ser arrojado a las aguas por su valor simbólico y exótico, ya que se trata de una pieza que pudo llegar a Onuba en un contexto cronológico y cultural del Bronce Final, bien a través del comercio con el Mediterráneo central por medio de navegantes indígenas, bien a través de los primeros contactos con los comerciantes fenicios instalados en Huelva, de forma coetánea a la construcción del conocido muro de contención del poblado indígena de San Pedro (Ruiz-Gálvez, 1998, 298). Así pues, en el gran depósito de la ría de Huelva se introducen ya algunos de los pilares prácticos del poder de las futuras aristocracias tar- tesias: la siderurgia del hierro y el uso del caballo como montura.

En el caso de que algunas de las piezas de bronce del depósito pudieran ser clasificadas como torques, hay que anotar la importancia sagrada de este elemento metálico en la cultura celta. Por las fuentes clásicas sabemos que era ofrecido no sólo a Marte, como apunta Floro (II, 4), sino también a otras divinidades al decir de Justino (XLIII 5, 1-10) y de Quintiliano (VI, 3), refiriéndose a época galo-romana. Desde una perspectiva arqueológica, las figuras que portan torques han sido interpretadas tradicionalmente como imágenes de dioses o de guerreros heroizados.

La deposición de otros tipos de piezas en el fondo de las aguas, como los restos de carros, parece responder a una sinécdoque: la parte identifica al todo. La presencia de carros, de piezas integrantes de estos vehículos o representaciones de ellos, se testifica bien en depósitos acuáticos europeos, como en Llyn Fawr, La Têne o Llyn Cerrig. La inmersión de carros o algunas de sus partes la expone con cierto detalle Tácito (Germania XL, 2-5), al describir el culto de los germanos a la diosa Nerthus. Otro testimonio de gran elocuencia lo brinda Orosio (Historiarum V, 16, 5-6), cuando relata con horror e incomprensión las prácticas rituales que tras la batalla de Arausio en el año 105 a.C. realizaron cimbrios y teutones. Y se testifica también sin problemas en algunos contextos funerarios tartesios del Hierro Antiguo. A tenor de estas piezas se observa un inicio del uso ceremonial del caballo en las poblaciones tartesias a partir de finales del Bronce (Huelva y Baioes), aunque el cambio más espectacular tiene lugar desde el siglo IX a.C. en adelante.

Podemos ir todavía un poco más allá en la interpretación de los arreos de caballos y restos de carro hallados en el fondo de la ría de Huelva ¿Su presencia en el fondo de las aguas pudo implicar el sacrificio obligatorio de los équidos?FFNo hay ningún resto que lo confirme como víctima sacrificial en este período, no así durante el orientalizante asociado a algún ambiente funerario, como se testifica en la necrópolis de La Joya (Huelva) o en la zona de Los Alcores (Sevilla). Teniendo en cuenta la importancia imaginaria que pudo desempeñar este animal, no resultaría extraño que mantuviese un papel fundamental en el sacrificio, como se atestigua entre los pueblos indoeuropeos. El sacrificio del caballo constituía una importante actividad ritual asociada a las jefaturas. 
Dentro del carácter militar o guerrero de los materiales llama la atención la aparente ausencia de restos pertenecientes a escudos metálicos, tanto porque en otras áreas europeas conforman un elemento destacado y específico en las deposiciones votivas acuáticas y terrestres, tales son los casos de los dieciséis escudos arrojados al lago Vänern (Suecia) o los hallados en sitios ingleses o irlandeses (por ejemplo en el sur de Cadbury, Somerset o en el Lago Gur, en Comty Limerick, Irlanda), como por el hecho de que aparezcan representados con gran profusión en las estelas decoradas del suroeste. De hecho, a tenor de estas imágenes pétreas no faltan especialistas que sugieren la existencia de una hoplolatría entre los tartesios del Bronce Final, incluso que tales representaciones sean la hipóstasis de alguna divinidad (Mederos, 2012, $430 \mathrm{ss}$ ).

En cuanto a la presencia de cascos en las aguas fluviales onubenses, se insertan junto a otros ejemplos de cascos griegos aparecidos en aguas fluviales del suroeste peninsular. Nos referimos al hallazgo de otro casco corintio de bronce de la primera mitad del siglo VII a.C. aparecido en el río Guadalete. Fue hallado en el año 1938 en el lecho de dicho río, cerca de Jerez de la Frontera. Un tercer casco ha sido ubicado en la desembocadura del Guadalquivir, en la zona de Sanlúcar de Barrameda, aunque conviene tener precaución con esta información debido a que procede del comercio de antigüedades (colección privada, Madrid). Ambos se datan también a mediados del VII a.C. Su deposición sido valorada como ofrendas propiciatorias o exvotos de marinos helenos o foráneos al traspasar un límite. Se les asocia igualmente a santuarios costeros vinculados a manantiales de agua dulce y a las leyes de la hospitalidad y derecho de asilo y de protección al extranjero. Precisamente, el agua junto a su función práctica y primaria está asociada a otras de contenido religioso, como la oracular (Olmos, 1992, 104-105).

Sin embargo, cabe pensar en la probabilidad de que la práctica cultual de arrojar cascos a los ríos hunda sus raíces en el ámbito ritual atlántico, previo a las colonizaciones fenicia y griega, reforzando de este modo el papel simbólico que determinados lugares de paso desempeñaron en el imaginario religioso de las poblaciones autóctonas del suroeste peninsular (Jiménez Ávila, 2002, 238 ss). Para otros especialistas, como R. Olmos, podría tratarse de una adaptación griega al rito indígena, donde el heleno sentiría a las divinidades locales no muy diferentes de las suyas propias (Olmos, 1986, 589).
Disponemos de algunas evidencias arqueológicas que podrían avalar el carácter vernáculo de esta práctica votiva. Además de los restos onubenses, si nos trasladamos al norte peninsular contamos con los “cascos” rituales de Leiro (Rianxo, La Coruña), Axtroki (Bolíbar, Guipúzcoa) y, en el sureste, el controvertido hallazgo del casco-cuenco de plata de Caudete de las Fuentes (Valencia), cuyos paralelos más fieles pueden fecharse en el Bronce Final e inicios de la Edad del Hierro. Una lectura funcional y simbólica reciente, los califica como bonetes o tocados sacerdotales decorados con una iconografía astral (Andrés, 2007-2008), si bien estos casquetes bajos y semiesféricos pueden ser considerados igualmente como emblemas de jefatura, tal y como se constata durante la Edad del Bronce en el Próximo Oriente y en la Europa nórdica, sin perder de vista que el príncipe o rey podía ser al mismo tiempo el líder ritual (Kristiansen y Larsson, 2006, 302-306).

Así mismo, es muy probable que la amortización ritual de cascos no declinara andando en el tiempo, como lo certifica la deposición de cascos de tipo Montefortino o hispano-calcídicos a partir de finales del siglo IV a.C. y el III a.C. Hay argumentos fiables que prueban que la mayoría de los yelmos recuperados en medios acuáticos pueden interpretarse como ritos: junto a su dilatada secuencia temporal, todas las piezas fueron halladas de forma aislada, salvo los casos de la ría de Huelva y Caudete de las Fuentes (Valencia). Así mismo, destaca la inutilización intencionada o fractura de alguna de sus partes. Ciertos especialistas han relacionado las ofrendas de estas armas defensivas con el ritual de la iactato (Graells y Lorrio, 2013, 160, 165 ss).

\section{LOS OFERENTES}

Parece claro que el estuario onubense fue el escenario acuático receptor de ofrendas durante casi seis siglos, lo que encuentra un refrendo argumental en el hallazgo de diversas piezas en lechos de otros ríos tiempo después de los últimos momentos del Bronce. Es el caso, entre otros, de los cascos griegos ya comentados o del jarro de bronce procedente de Alcalá del Río.

Para sostener nuestra argumentación cultual, debe traerse a colación el hecho de que en los últimos años han sido exhumados en Huelva un conjunto de estructuras y materiales en primera línea de costa susceptibles de ser interpretados como pertenecientes a un lugar de culto empórico o indígena. Nos referimos a los citados restos arqueológicos 
desenterrados en una intervención de urgencia en la calle Méndez Núñez 7-13, esquina con la plaza de las Monjas (González de Canales et al., 2004). De sobra es conocida la asociación de armas a santuarios mediterráneos y celtas (Gabaldón, 2004) ${ }^{8}$ o, incluso, a residencias aristocráticas que no tienen porqué haber dejado huellas arqueológicas. En este último caso, se puede evocar la erección de casas de elite convertidas en trofeos, como testifican los textos (Alceo, 140) y la iconografía vascular del mundo griego.

Defendemos la hipótesis de que los depósitos aislados representan ofrendas individuales, mientras que los grupos de piezas amortizadas juntas deben ser ofrendas comunales. El poder del ritual dependería en gran medida de la cantidad de material sacrificado. En tal sentido, es posible que el estuario onubense fuera el escenario de culto de distintos grupos tribales o de linajes de la zona, tal y como plantea alguna autora (Delgado, 2008, 353 ss.). Es posible que hubiera coaliciones de tribus, y que se firmaran acuerdos entre tribus y poblados para regular unos derechos de pastoreo, matrimonio y comercio. La función de tales sitios durante el final del Bronce recuerda el papel que tenían otros lugares naturales en algunas poblaciones antiguas (Bradley, 2006). Nos referimos, por ejemplo, a los bosques sagrados entre la tribu germánica de los semmones, dentro de sus cultos de cohesión que perseguían potenciar las especificidades tribales, tal y como describe Tácito en su obra Germania (XXXIX, 2-3). Tanto en este caso como en el depósito de la ría de Huelva, el sacrificio o la ofrenda, así como la aceptación del lazo religioso sellan la pertenencia al grupo tribal, que representa al mismo tiempo el grupo de los cultores de la divinidad específica. Puede comprobarse como la religión es el medio de mantener los lazos de cohesión del grupo, y la amortización de riquezas, el vehículo para consolidar las decisiones comunes en el marco de actos públicos.

Para algunos autores, la diversidad de orígenes de los metales - procedentes tanto del sureste como de Cerdeña- es un buen argumento para sostener la idea de que Huelva fue un enclave estratégico donde concurrieron diferentes corrientes de intercambios y contactos cíclicos que dieron lugar a

8 Algunos especialistas sostienen que los depósitos de armas hallados en contextos fluviales son el resultado de la liquidación de trofeos expuestos en santuarios cercanos; por ejemplo, von Nicolai, 2012, 47-48. una zona ritualizada de deposición desde el Bronce Final, permitiendo a las élites locales vincularse a vastos territorios (Montero et al., 2007, 208). Los materiales y estructuras hallados en el solar onubense ofrecen la impresión de que los jefes locales tartesios del Bronce Final crearon una compleja red de alianzas capaz de garantizar los símbolos materiales del éxito. Huelva y su región lograron diferenciarse lo suficiente de las áreas vecinas como para reestructurar su producción e implicarse en un comercio desigual. Cabría hablar en este sentido de la emergencia de una auténtica jefatura marítima. Sin embargo, la misma información arqueológica sigue describiendo una sociedad todavía insuficientemente estable y ordenada, donde la lucha territorial y la competitividad parecen importantes.

\section{Bibliografía}

Albelda, J. (1923), "Bronzes de Huelva (Espagne)". Révue Archéologique, XVIII, Vé serie, 222226.

Albelda, J. y Obermaier, H. (1988), "El casco griego de Huelva”, Reimpresión de la Excma. Diputación provincial de Huelva, Clásicos de la Arqueología de Huelva I, 11-29.

Alfayé, S. (2009), Santuarios y rituales en la Hispania Céltica, BAR International Series 1963, Oxford.

Almagro Basch, M. (1940), "El hallazgo de la ría de Huelva y el final de la Edad del Bronce en el Occidente de Europa”, Ampurias, 2, 85-143.

(1958), Depósito de la Ría de Huelva, Inventaria Archaeologica, Instituto de Prehistoria y Dirección General de Bellas Artes, Madrid.

Almagro-Gorbea, M. (1977), El Bronce Final y el Periodo Orientalizante en Extremadura, Bibliotheca Praehistorica Hispana XIV.

(2009), "La Edad del Bronce", Prehistoria y Antigüedad. Historia militar de España (M. Almagro-Gorbea, Coord.), Laberinto y Ministerio de Defensa, Madrid, 49-60.

Alonso Fernández, C. y Jiménez Echevarría, J. (2009), "El depósito de armas del Bronce Final de "Los Cascajos” Grañón (La Rioja)”, Gladius, XXIX, 7-38.

Andrés Rupérez, M. T. (2007-2008), "Semblanza cosmográfica de los "cuencos" de Axtroki”, Veleia, 24-25, 879-894.

Belén, M. y Escacena, J. L. (1992), "Las necrópolis ibéricas de Andalucía occidental”, Congreso de Arqueología Ibérica. Las Necrópolis (Se- 
rie Varia 1), J. Blánquez y V. Antona (coord.), Universidad Autónoma de Madrid, 509-529, Madrid.

Belén, M. et al. (1991), "El mundo funerario del Bronce Final en la fachada atlántica de la Península Ibérica. I. Análisis de la documentación", Trabajos de Prehistoria, no 48, 225-256.

Blázquez, J. M. y García-Gelabert, M. P. (1997), "El culto a las aguas en la Hispania prerromana”, Termalismo antiguo, I, Congreso Peninsular (Pérex Agorreta, $\mathrm{M}^{\mathrm{a}} \mathrm{J}$., Ed.), Madrid, 105-115.

Bradley, R. (2005), Ritual and Domestic Life in Prehistoric Europe, Routlegde, London-New York.

(2006), An Archaeological of Natural Places, Routledge, London, New York.

Bradley, R. y Gordon, K. (1988), "Human Skulls from the River Thames, Their Dating and Significance", Antiquity, 62, 503-509.

Brandherm, D. (2007), Las Espadas del Bronce Final en la Península Ibérica y Baleares, Prähistorische Bronzefunde, Abteilung IV, 16, Band, Franz Steiner Verlag Stuttgart.

(2008), "Vasos a debate. La cronología del Geométrico griego y las primeras colonizaciones en el occidente", Contacto cultural entre el Mediterráneo y el Atlántico (siglos XII-VIII ane). La precolonización a debate (S. Celestino et al., Eds.), CSIC, Escuela Española de Historia y Arqueología en Roma, 93-106.

(2008-2009), "Sobre los supuestos arreos de caballo y piezas de carro de la Ría de Huelva”, Homenaje al Dr. Michael Blech, Boletín de la Asociación Española de Amigos de la Arqueología, 45, 27-33.

(2011), "Bronzezeitliche Kamm - und hörnerhelme - überlegungen $\mathrm{zu}$ ursprung, verbreitung und symbolischem gehalt", Bronzen im Spaaungsfeld zwischen praktischer Nutzung und symbolischer Bedeutung, U. T. Dietz y A. Jockenhövel (Eds.), Prähistorische Bronzefunde, Abteilung XX, Band 13, 39-54.

Brandherm, D. y Meskal-del Hoyo, M. (2010), "Las espadas en lengua de carpa -aspectos morfológicos, metalúrgicos y culturales", Trabajos de Prehistoria, 67, 2, 431-456.

Carrasco, J. et al. (2012), "Fíbulas de codo "tipo Huelva" en la Península Ibérica: nuevos datos y comentarios historiográficos", Trabajos de Prehistoria, 69, 2, 310-331.

Carriazo, J. de Mata (1947), "La Edad del Bron- ce”, Historia de España I(R. Menéndez Pidal, Ed.), Madrid, 753-852.

Coffyn, A. (1985), Le Bonze Final Atlantique dans la Peninsule Iberique, París.

Cuadrado, E. (1969), "Las fíbulas anulares de la Ría de Huelva”, Archivo Español de Arqueología, XLII, 40-43.

Delgado, A. (2008), "Fenicios en Iberia”, De Iberia a Hispania (F. Gracia, Coord.), Madrid, 347474.

Delibes de Castro, G. et al. (2007), "Reivindicación de un polémico depósito del Bronce Final atlántico: La Morterona (Saldaña, Palencia)”, El hallazgo leonés de Valdevimbre y los depósitos del Bronce Final atlántico en la Península Ibérica (J. Celis et al., Eds.), Estudios y Catálogos 17, Museos de Castilla y León, Junta de Castilla y León y Diputación de León, 330-351.

Díaz, J. (1923), "Objetos de bronce en la ría de Huelva”, Actas y Memorias de Sociedad Española de Antropología, Etnografía y Prehistoria, 2/1, 37-40.

Escacena, J. L.(2000), La arqueología protohistórica del sur de la Península Ibérica. Historia de un río revuelto, Editorial Síntesis, Madrid.

Fernández Jurado. J. (2005), "Y por fin llegaron fenicios..., a Huelva", El periodo orientalizante, Actas del III Simposio Internacional de Arqueología de Mérida: Protohistoria del Mediterráneo Occidental (S. Celestino y J. Jiménez, Eds.), Anejos de Archivo Español de Arqueología, XXXV, II, 731-747.

Ferrer, E. (1991), "Notas aclaratorias sobre el escarabeo de la ría de Huelva", Habis, 22, 411-416.

(2012), "El brazo poderoso de Dios. Sobre un nuevo bronce fenicio de procedencia subacuática”, $L a$ Religión del Mar. Dioses y ritos de navegación en el Mediterráneo antiguo (E. Ferrer et al., Coords.), Spal Monografías, XVI, 37-66.

Ferrer, E. et al. (1997), "Dos notas sobre el depósito de la Ría de Huelva”, Spal, 6, 67-85.

Gabaldón, M. M. (2001), "Los rituales de armas de los pueblos del Norte de Europa. El "sacrificio" del botín”, Boletín de la Asociación Española de Amigos de la Arqueología, 41, 93-110.

(2004), Ritos de armas en la Edad del Hierro. Armamento y lugares de culto en el Antiguo Mediterráneo y el mundo celta, Anejos de Gladius, Madrid.

Gamer-Wallert, I. (1982), "Zwei Statuetten syroägyptischer Gottheiten von der Barra de Huel- 
va”, Madrider Mitteilungen, 23, 46-61.

García Bellido, A. (1970), "Escarabeo en bronce de Amenophis III (1408-1372) de la ría de Huelva”, Boletín de la Real Academia de la Historia, 166, 61-62.

García Sanjuán, L. (2005), "Grandes piedras viejas, memoria y pasado. Reutilizaciones del dolmen de Palacio III (Almadén de la Plata, Sevilla) durante la Edad del Hierro", El período Orientalizante,I, Actas del III Simposio Internacional de Arqueología de Mérida: Protohistoria del Mediterráneo Occidental (Celestino, S. y Jiménez, J., Eds.), Anejos de Archivo Español de Arqueología, 595-604.

Gener, M. et al. (2009), "Hasta aquí puedo leer". Discusión sobre un estudio de fragmentos de espadas del Bronce Final del depósito de la Ría de Huelva”, MetalEspaña'08 (J. Barro y E. Cano, Coords.), Madrid, 234-241.

Gómez-Moreno, M. (1923), "Hallazgo arqueológico en el Puerto de Huelva", Boletín de la Real Academia de la Historia, 83, 89-91.

González de Canales, et al. (2004), El emporio fenicio precolonial de Huelva (ca. 900-770 a.C.), Biblioteca Nueva, Madrid.

González-Ruibal, A. (2006-2007), Poder y comunidad en el Noroeste de la península Ibérica (1200 a.C.-50 d.C.), Brigantium, 18/I-II.

Gracia Alonso, F. (2003), La Guerra en la Protohistoria. Héroes, nobles, mercenarios y campesinos, Ariel Prehistoria, Barcelona.

Graells i Fabregat, R. y Lorrio, A. J. (2013), "El casco celtibérico de Muriel de la Fuente (Soria) y los hallazgos de cascos en las aguas en la Península Ibérica”, Complutum, 24/1, 151-173.

Harding, A. (2003), Sociedades europeas en la Edad del Bronce, Ariel Prehistoria, Barcelona.

Hunt, M. A. (2001), "El Depósito de la Ría de Huelva: Datos Isotópicos para la determinación de su Procedencia”. Actas del III Congreso $\mathrm{Na}$ cional de Arqueometría (Gómez Tubío et al., Eds.), Sevilla, 487-496.

Jantzen, D. et al. (2011), “A Bronze age battlefield? Weapons and trauma in the Tollense valley, north-eastern Germany”, Antiquity 85, 417-433.

Jensen, X. P. (2012), "Les armes sacrifiées au Nord -les armes votives de l'Antiquité scandinave", Les armes dans les eaux. Questions d'interprétation en Archéologie (Testart, A., Dir.), Paris, 167-192.

Jiménez Ávila, J. (2002), La toréutica orientali- zante en la Península Ibérica, Real Academia de la Historia, Madrid.

Kaiser, J. M․ . 2003), "Puntas de flecha de la Edad del Bronce en la Península Ibérica". Producción, circulación y cronología”, Complutum, 14, 73106.

Kristiansen, K. y Larsson, T. (2006), La emergencia de la sociedad del Bronce. Viajes, transmisiones y transformaciones, Bellaterra, Barcelona.

Lagarde, C. y Pernot, M. (2009), "Les pratiques de dépôts métalliques en Aquitaine à l'âge du Bronze moyen (XVI-XIV siècle av. J.-C.): une analyse multicritère", Du matériel au spirituel. Réalités archéologiques et historiques des "dépôts" de la Préhistoire à nos tours (C. Bonnardin et al., Dirs.-), Antibes, 175-181.

Llobregat Conesa, E. (1963),”Una espada inédita del hallazgo de Huelva", Actas del VIII Congreso Nacional de Arqueología, 324-326.

Martín Ruiz, J. A. (2010), "El comercio cananeo y fenicio a través del cargamento transportado en los pecios hallados en el Mediterráneo", Revista Atlántica-Mediterránea de Prehistoria y Arqueología Social, 12, 127-138.

Mederos, A. (1996), "La conexión levantino-chipriota. Indicios de comercio atlántico con el Mediterráneo oriental durante el Bronce Final (1150-950a.C.)”, Trabajos de Prehistoria, 53/2, 95-115.

(2006), "Fenicios en Huelva, en el siglo X a.C., durante el reinado de Hîrãm I de Tiro”, Spal, 15, 167-188.

(2008a), "El Bronce Final”. De Iberia a Hispania (F. Gracia, Coord.), Ariel Prehistoria, 19-91, Madrid.

(2008b), "Las espadas de tipo Huelva y los inicios de la presencia fenicia en occidente durante el bronce final IIC-IIIA 1150-950 AC”, Cuadernos de Prehistoria y Arqueología de la Universidad Autónoma de Madrid, 34, 41-75.

(2012), "El origen de las estelas decoradas del Suroeste de la Península Ibérica en el Bronce Final II (1325-1150 a.C.)", Sidereum Ana II. El rio Guadiana en el Bronce Final (J. Jiménez, Ed.), Anejos de Archivo Español de Arqueología, LXII, 417-454.

Meijide Cameselle, G. (1988), Las Espadas del Bronce Final en la Península Ibérica, Santiago de Compostela.

Milcent, P.-Y.(2012), Le temps des élites en Gau- 
le Atantique. Chronologie des mobiliers et rythmes de constitution des dépots métalliques Dans le contexte européen $\left(X I I I^{E}-V I I^{E} S\right.$. $A V$. J.-C.), Rennes.

Montero, I. et al. (2002), "Espadas y puñales del Bronce Final: el depósito de armas de Puertollano (Ciudad Real)", Gladius, XXII, 5-28.

Montero, I et al. (2007), "El depósito de la ría de Huelva: procedencia del metal a través de los resultados de análisis de isótopos de plomo”, $E l$ hallazgo leonés de Valdevimbre y los depósitos del Bronce Final atlántico en la Península Ibérica (J. Celis et al., Eds.), Estudios y Catálogos 17, Museos de Castilla y León. Junta de Castilla y León y Diputación de León, León, 194-209.

Montero, I. et al. (2008), "Technological study of swords from Ría de Huelva hoard (Spain)", $34^{\text {th }}$ International Symposium on Archaeometry 2004, 3-7 may, Zaragoza, Institución Fernando el Católico, Zaragoza.

Nebelsick, L. (2000), "Rent Asunder, Ritual Violence in Late Bronze Age Hoards", Metals Make the World go Round, the Supply and Circulation of Metals in Bronze Age Europe (Ch. Pare, Ed.), Proceedings of a conference held at the University of Birmingham in June 1997, Oxford, 160-175,.

Olmos, R. (1988), "El Casco Griego de Huelva”, El casco griego de Huelva, Clásicos de Arqueología de Huelva, 1 (Reimpresión de H. Obermaier, 1931), Huelva, 39-79.

(1986), "Los griegos en Tarteso: replanteamiento arqueológico-histórico del problema", Homenaje a Luis Siret, 584-600.

(1992), "Iconografía y culto a las aguas de época prerromana en los mundos colonial e ibérico", Espacio, Tiempo y Forma, Serie II, H ${ }^{\mathrm{a}}$. Antigua, V, 103-120.

Quesada, F. et al. -Coords.- (2010), De armas, de hombres y de dioses. El papel de las armas en la conquista romana de la península Ibérica, Gladius, 30.

Quilliec, B.T. (2007a),"Vida y muerte de una espada atlántica del Bronce Final en Europa: Reconstrucción de los procesos de fabricación, uso y destrucción”, Complutum, 18, 93-107.

(2007b), L'épée atlantique: échanges et prestige au Bronze final, Société Préhistorique Française, Mémoire XLII, Paris.

Rovira, S. (1995), "Estudio arqueometalúrgico del depósito de la ría de Huelva”, Ritos de paso y puntos de paso. La Ría de Huelva en el mundo del Bronce Final europeo (Ruiz-Gálvez, $\mathrm{M}^{\mathrm{a}}$. L., Ed.). , 33-57.

(2007), "Las espadas del Bronce Final de la Península Ibérica: estudio arqueometalúrgico", en Branherm, D.: Las Espadas del Bronce Final en la Península Ibérica y Baleares, Prähistorische Bronzefunde, Abteilung IV, 16, Band, Franz Steiner Verlag Stuttgart, 155-175.

Rouillard, P. (1977): "Fragmentos griegos de estilo geométrico y corintio medio en Huelva”, en Belén et al., Los orígenes de Huelva, Huelva Arqueológica, III, 397-401.

Ruiz-Gálvez, M. -Ed.- (1995a), Ritos de paso y puntos de paso. La Ría de Huelva en el mundo del Bronce Final europeo, Complutum Extra, 5, Madrid.

(1995b), "Circulación del metal en el Bronce Final del Suroeste”, Tartessos: 25 años después, 1968-1993, Jerez de la Frontera, 507-521.

(1998), La Europa atlántica en la Edad del Bronce. Un viaje a las raíces de la Europa occidental, Barcelona.

(2005), "Der fliegende mittlemeermann. Piratas y héroes en los albores de la Edad del Hierro", $E l$ periodo orientalizante. Actas del III Simposio Internacional de Arqueología de Mérida: Protohistoria del Mediterráneo Occidental, I (S. Celestino y J. Jiménez, Eds.), Anejos de Archivo Español de Arqueología, XXXV, Madrid, 251-275.

(2013), Con el fenicio en los talones. Los inicios de la Edad del Hierro en la cuenca del Mediterráneo, Barcelona.

Samson, A. V. M. (2006), "Offshore finds from the Bronze Age in North-Western Europe: The Shipwreck Scenario Revisited", Oxford Journal of Archaeology, 25/4, 371-388.

Schauer, P. (1983), "Orient im spätbronze und früheisenzeitlichen Occident. Kulturbeziehungen zwischen der Iberischen Halbinsel und dem Vorderen Orient während des späten 2en. und des ersten Drittels des 1. Jahrtausends c.Chr.”, Jahbuch des römisch-germanischen Zentralmuseums, Mainz, 175-194.

Terrero, J. (1944), Armas y objetos de bronce extraidos en los dragados del puerto de Huelva, Clásicos de la Arqueología de Huelva, 3, Huelva.

Testart, A. -Dir.-(2012), Les armes dans les eaux. 
Questions d'interprétation en Archéologie, París.

Von Nicolai, C. (2012), "Historique des interprétations, du XIX ${ }^{\mathrm{e}}$ siécle á nos tours”, Les armes dans les eaux. Questions d'interprétation en Archéologie (A. Testart, Dir.), Paris, 17-51. 